32

\title{
The 1987 to 2019 Tennant Creek, Australia, earthquake sequence: a protracted intraplate multi-mainshock sequence
}

Tamarah R. King

School of Earth Sciences, The University of Melbourne, Victoria 3010, Australia tamarah.king@unimelb.edu.au https://orcid.org/0000-0002-9654-2917

Mark Quigley

School of Earth Sciences, The University of Melbourne, Victoria 3010, Australia

Mark.quigley@unimelb.edu.au

https://orcid.org/0000-0002-4430-4212

\section{Dan Clark}

Geoscience Australia, Canberra, ACT 2601, Australia

https://orcid.org/0000-0001-5387-4404

\section{Sotiris N. Valkaniotis}

Koronidos 9, 42131 Trikala, Greece

https://orcid.org/0000-0003-0003-2902

Hiwa Mohammadi

School of Earth Sciences, The University of Melbourne, Victoria 3010, Australia

William Barnhart

Department of Earth and Environmental Sciences, The University of Iowa, USA https://orcid.org/0000-0003-0498-169

This document presents a review of available literature related to 1989 Tennant Creek surface rupturing earthquakes, and new data describing the 2019 Tennant Creek earthquake.

We intend to produce a second iteration of this report which extends the analysis and interpretation for the $1^{\text {st }}$ August $2019 \mathrm{M}_{\mathrm{w}} 5.0$ aftershock including additional Coulomb stress modelling, fault source modelling, and geophysical analysis.

The review section of this document supplements a manuscript reviewing all Australian surface rupturing earthquakes, submitted to Geosciences in August 2019.

Please contact authors on the content presented herein; we welcome constructive feedback. 


\section{Abstract}

The 1987 to 2019 Tennant Creek earthquake sequence comprises three 1988 surface-rupturing mainshocks (moment magnitude $\left(\mathrm{M}_{\mathrm{w}} 6.2,6.3\right.$, and 6.5) that occurred within a 12-hour period, a preceding foreshock sequence commencing in 1987, and a prolonged aftershock sequence including a $\mathrm{M}_{\mathrm{w}} 5.0$ earthquake on the $1^{\text {st }}$ August 2019. Each surface rupturing event produced a distinct scarp; the south-dipping Kunayungku scarp, north-dipping Lake Surprise west scarp and south-dipping Lake Surprise east scarp. Fault geometries were confirmed by trenches across the rupture traces, levelling surveys across the rupture traces, newly acquired satellite-derived high-resolution elevation data, and well-located aftershocks. Focal mechanisms and modelling using available seismic data support the hypothesis that the first mainshock ruptured the Kunayungku fault, the second mainshock ruptured the Lake Surprise west fault (and potentially rupturing across multiple other blind faults), and the third mainshock ruptured the Lake Surprise east fault. Trenching across all three ruptures found no evidence of prior rupture along the Lake Surprise east and Kunayungku faults. Potential evidence of prior rupture on the Lake Surprise west scarp has been reported. However, we consider this evidence to be circumstantial and to equally support an alternative interpretation; that the pre- 1988 topography relates to a paleo-channel along underlying bedrock topography. Surface rupture locations and orientations are strongly aligned to underlying linear geophysical anomalies, suggesting strong control of bedrock structure on contemporary seismicity. Almost 31 years after the initial sequence, a $\mathrm{M}_{\mathrm{w}} 5.0$ aftershock was recorded near the western tip of the West Lake Surprise rupture. InSAR fault modelling suggests this occurred on a shallow blind fault $(<2 \mathrm{~km}$ depth to top of fault). This structure is also aligned with linear geophysical anomalies, providing further support that pre-existing basement structures are providing strong controls on the location and geometry of faulting in this intraplate stable continental region.

\section{Introduction}

On the $22^{\text {nd }}$ January 1988 , three earthquakes of $\mathrm{M}_{\mathrm{w}} 6.3,6.4$ and 6.6 occurred within a $12 \mathrm{hr}$ period and $5-10 \mathrm{~km}$ radius of each other $30 \mathrm{~km}$ south-west of Tennant Creek (Figure 1), a remote town in the Northern Territory of Australia. These were the fifth, sixth and seventh instrumentally recorded surface rupturing events within Australia, forming the south-west dipping Kunayungku scarp, northwest dipping Lake Surprise west scarp, and south-west dipping Lake Surprise east scarp reported as $10.2,6.7$ and $16 \mathrm{~km}$ long respectively (Crone et al., 1992). These events were preceded by six $\mathrm{M}_{\mathrm{L}} 4.0$ -5.0 events from $5-9^{\text {th }}$ January 1987 (12 months prior to the mainshocks). Up to 1,100 aftershocks from this seismic sequence were recorded in the 12 months leading up to the $22^{\text {nd }}$ January 1988 mainshocks Bowman (1997). Over 20,000 aftershocks were recorded between 1988 and 1992 (Bowman, 1992) following the three 1988 mainshocks. The largest of these include a $\mathrm{M}_{\mathrm{b}} 5.8\left(\mathrm{M}_{\mathrm{w}} 5.3\right)$ event recorded nine hours after the third mainshock, a $\mathrm{M}_{\mathrm{b}} 5.5\left(\mathrm{M}_{\mathrm{w}}\right.$ 5.4) seven days later, and $\mathrm{a} \mathrm{M}_{\mathrm{b}} 5.2$ $\left(M_{w} 4.9\right)$ eight months later $\left(M_{w}\right.$ values from (Allen et al., 2018b)). Since 1990, there have been four $\mathrm{M}_{\mathrm{w}}>5.0$ aftershocks, in 1990, 1991, 1994 and 1999 (from the NSHA18 catalogue (Allen et al., 2018b)).

On the $1^{\text {st }}$ August 2019, a $\mathrm{M}_{\mathrm{w}} 5.0\left(\mathrm{M}_{\mathrm{b}} 5.4 \mathrm{USGS}, \mathrm{M}_{\mathrm{L}} 5.3 \mathrm{GA}\right)$ aftershock occurred, the largest since 1999 , with five $M_{L} 2.5-3.6$ events in the 20 days following the event (up to $20^{\text {th }}$ August 2019, Geoscience Australia online catalogue). InSAR data shows this earthquake ruptured a shallow NWSE trending fault west of the 1988 Lake Surprise west scarp, and south of the 1988 Kunayungku scarp, but did not produce a surface rupture.

In this contribution we review available geological, seismological, surface observations and paleoseismology for the 1988 mainshocks, and provide InSAR derived fault models and preliminary Coulomb stress modelling to describe the 2019 aftershock. The sequence provides a prime example of a 'multiple mainshock' type of intraplate earthquake (Choy and Bowman, 1990), and a prolonged 
81 (multi-decade) aftershock sequence as observed in other intraplate stable continental regions (e.g.

82 New Madrid, USA) (Stein and Liu, 2009).

\section{2. Geology}

\subsection{Regional}

The Paleoproterozoic Tennant Region (Figure 1) is subdivided into the Tomkinson, Davenport and Warramunga Provinces, and is surrounded by onlapping Phanerozoic basins (Claoué-Long et al., 2008; Donnellan, 2013; Maidment et al., 2013, 2013). Boundaries between provinces are loosely defined due to poor bedrock exposure, and terminology and the names of the Provinces vary in the literature (e.g. (Betts et al., 2002; Blake and Page, 1988; Compston, 1995; Crone et al., 1992; Donnelly et al., 1999)). This paper uses the division locations and names of Donnellan (2013).

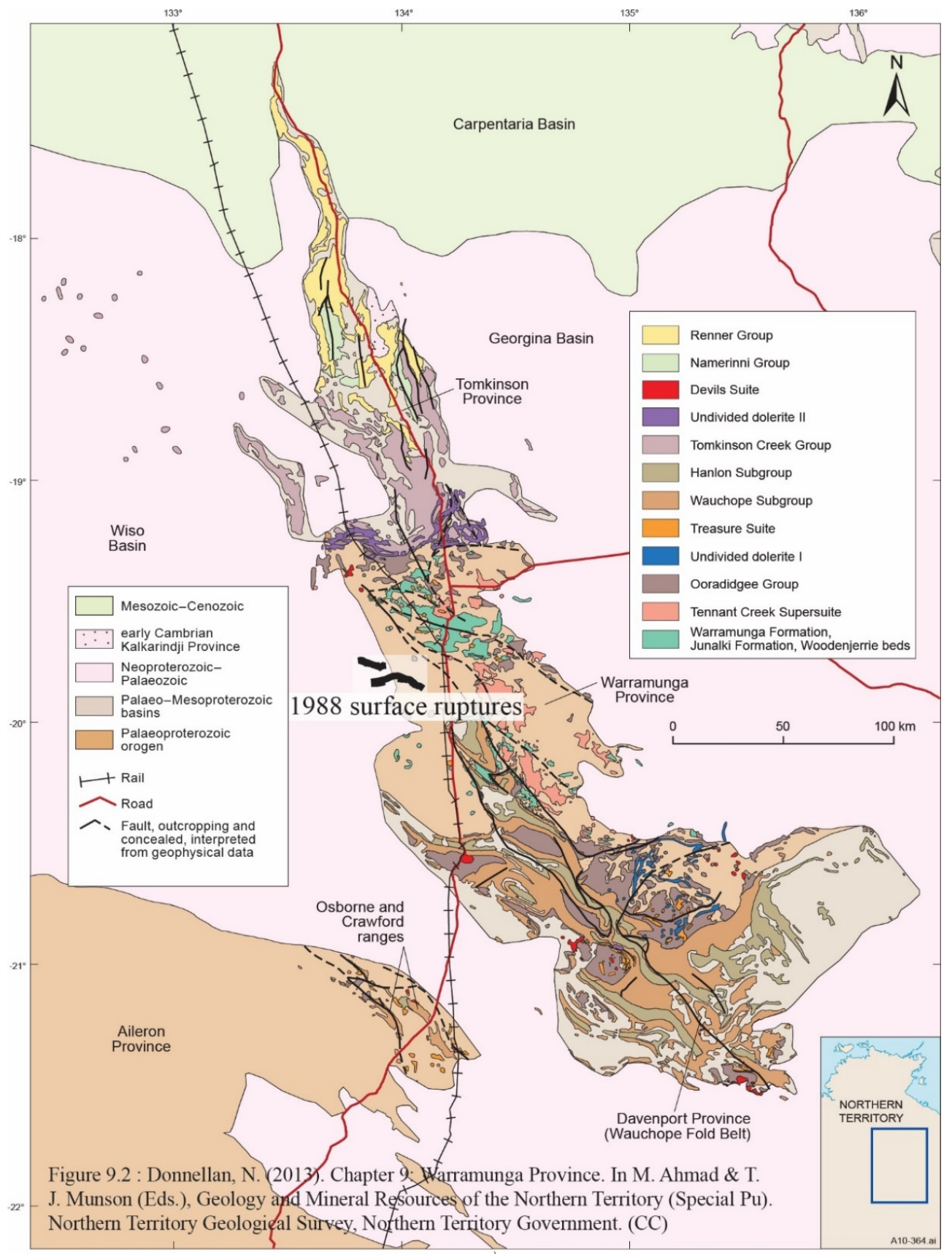

Figure 1: Provinces and regional geology of the Tennant Creek area with location of the 1988 Tennant Creek surface ruptures overlaid. Figure sourced from Donnellan (2013) used under creative commons from the Northern Territory of Australia (Northern Territory Geological Survey) 
The three 1988 Tennant Creek mainshocks and surface ruptures occurred on the western edge of outcrop relating to the central Warramunga Province, with two of the three scarps extending across the mapped boundary into the Neoproterozoic - Palaeozoic Wiso Basin (Figure 1). The Warramunga Province contains the oldest rocks of the Tennant Region (Cawood and Korsch, 2008; Donnellan, 2013) and is made up of mafic and felsic intrusive rocks, sedimentary rocks, and volcanic / volcaniclastic deposits (Donnellan, 2013; Donnelly et al., 1999; Johnstone and Donnellan, 2001). These rocks are variably metamorphosed and were poly-deformed during multiple orogenic events including the Tennant Event (ca $1850 \mathrm{Ma}$ ), Murchison Event (ca 1815 - $1805 \mathrm{Ma}$ ) and Davenport event (post $1790 \mathrm{Ma}$ ) (Donnellan, 2013; Maidment et al., 2013).

\section{$2.2 \quad$ Local bedrock}

Bore-water wells in the area surrounding the Kunayungku scarp (the western most surface rupture, Figure 2) show bedrock as Proterozoic granite overlain by 10's to 100's of meters of sediments (either from the Wiso Basin, or paleo-valley deposits) and 2-10 $\mathrm{m}$ of Cenozoic eolian sediments (Bowman et al., 1990; Verhoeven and Russell, 1981). Multiple normal faults were inferred through basement and Wiso Basin sediments based on changes in lithological depth of $50-80 \mathrm{~m}$ between wells, including directly below the Kunayungku scarp (Bowman et al., 1990; Verhoeven and Russell, 1981).

The Lake Surprise west scarp (Figure 2) is described by authors investigating the rupture as co-linear with a quartz ridge (Bowman, 1988; Bowman et al., 1988; Crone et al., 1992; Jones et al., 1991) which likely represents vein-quartz formed along a bedrock fracture. Crone et al. (1992) provide the most detailed description of this feature with dimensions $10-15 \mathrm{~m}$ high, $1.6 \mathrm{~km}$ long, $30-150 \mathrm{~m}$ wide, and $0.5 \mathrm{~km}$ west of the surface rupture, composed of "dark-red to maroon hematitic quartzite that is intensely fractured and mineralized with vein-filling, milky quartz". They note small bedrock outcrops along the ridge but do not provide descriptions of the lithology. Trenches across the Lake Surprise west scarp show that eolian sand is shallowly underlain by extensively altered quartzite (Crone et al., 1992), described as coarse-grained, unfractured and unjointed, hematitic and massive in places. Descriptions are not clear enough to know if this represents a known unit within the Warramunga Province, part of a Wiso Basin assemblage, a silcrete developed within another unit, or vein quartz related to the nearby quartz ridge.

Over 150 ground-water wells are present within $1 \mathrm{~km}$ of the Tennant Creek surface ruptures, most with accompanying stratigraphic logs (Figure 2) ${ }^{1}$. Between the Lake Surprise west and Kunayunku scarps, bore data show diorite at $>24 \mathrm{~m}$ overlain by sediments. Bores within $100 \mathrm{~m}$ of the Lake Surprise east scarp show weathered granite at variable depths $(48-100 \mathrm{~m})$ overlain by sandstones, siltstones, ironstones and gravel.

\footnotetext{
${ }^{1}$ Data available from the Northern Territory Government: http://nrmaps.nt.gov.au/nrmaps.html
} 


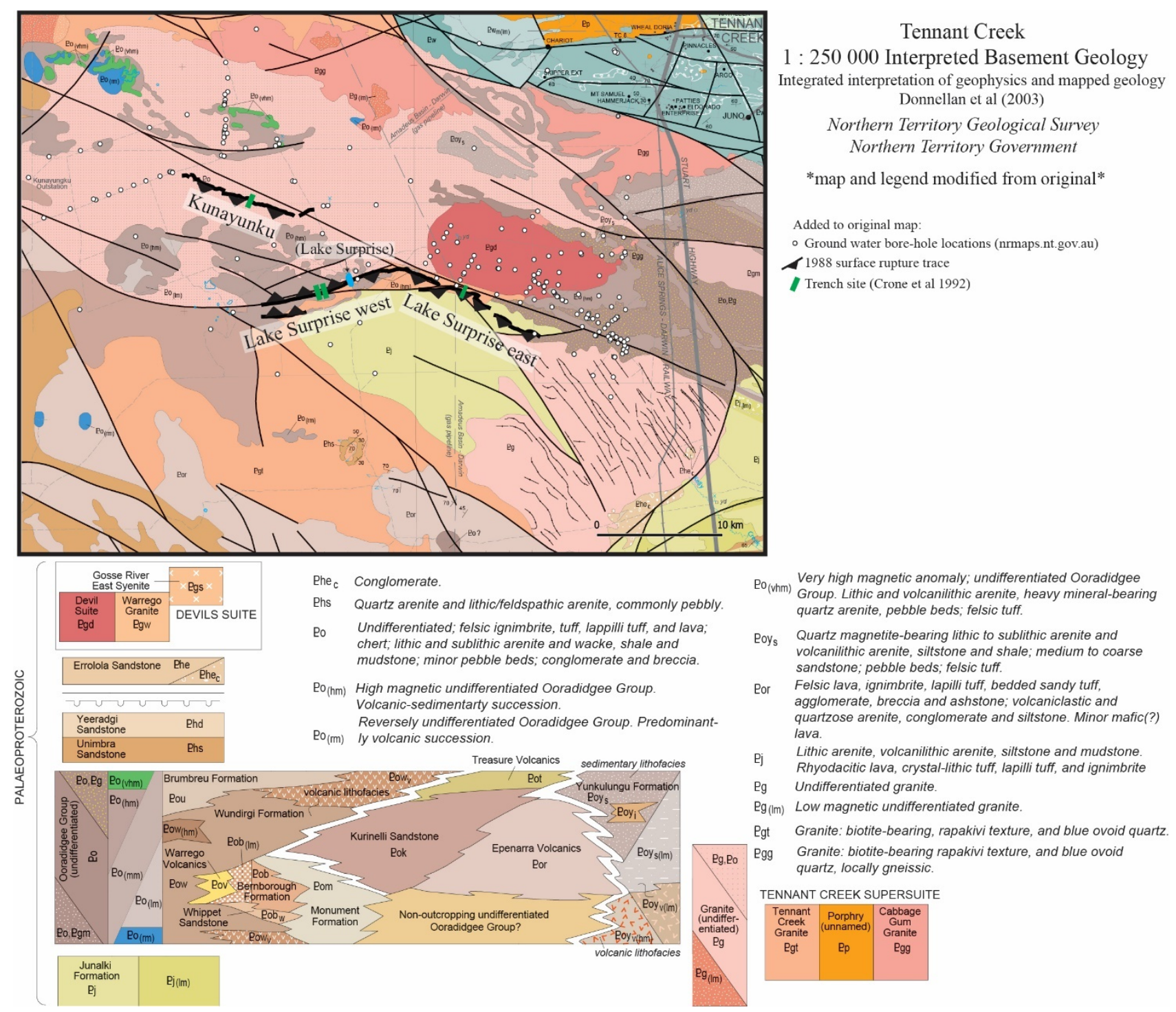

Figure 2. Crop of $1: 250000$ Tennant Creek interpreted basement geology map (Johnstone and Donnellan, 2001) with Tennant Creek scarps, trench sites of Crone et al. (2003) and bore-hole locations (NT Gov). Original map and legend (Johnstone and Donnellan, 2001) used under creative commons from the Northern Territory of Australia (Northern Territory Geological Survey)

127 Bedrock distribution interpreted from geophysical data and mapped geology (Johnstone and

128 Donnellan, 2001) (Figure 2) shows undifferentiated granite underlying Wiso Basin sediments beneath 129 the Kunayungku scarp. Basement underlying the Lake Surprise scarp is interpreted to consist of 130 volcanoclastic and sedimentary units in faulted contact with each other and intruded by granites of the 131 Tennant Creek Supersuite and Devils Suite. A large through-going basement structure is mapped $\sim 200-500 \mathrm{~m}$ north of the Kunayungku and Lake Surprise east scarps (Figure 2), visible as both a gravity and magnetic anomaly (Figure 3). The geometry of these faults and lithological / intrusive boundaries is unknown, but presumably could be better constrained by analysis of available bore-hole 135 lithological logs.

136 A gravity high occurs between the Kunayungku and Lake Surprise west scarps (Figure 3), with a 137 NW-SE trending boundary coincident with the Kunayungku surface rupture trend and location 138 (Bowman et al., 1990; Johnstone and Donnellan, 2001). This was originally modelled as an $20 \mathrm{~km}$ 
wide intrusive body with $500 \mathrm{~kg} \mathrm{~m}^{-3}$ density contrast extending from a depth of $1.2-10 \mathrm{~km}$ (Bullock, 1977). All three scarp locations correlate with the edges of magnetic highs.
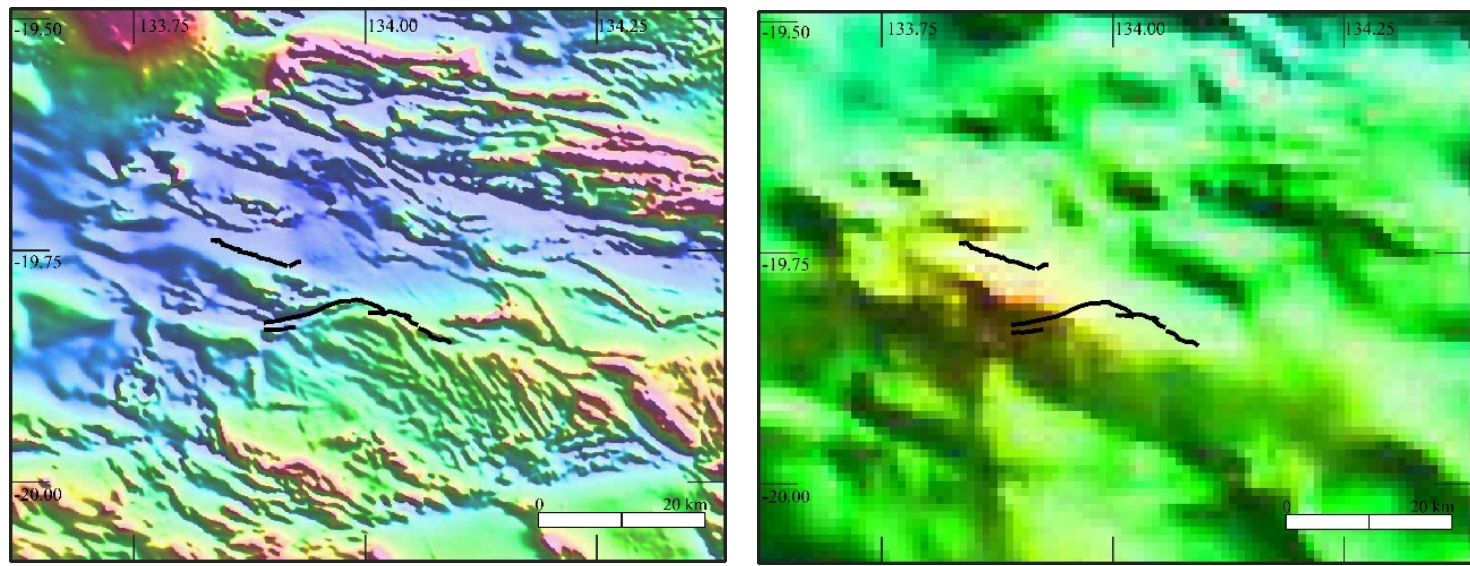

Figure 3. Tennant Creek scarp (black lines) relative to magnetic intensity and bouguer gravity anomaly maps. National bouguer gravity anomaly map: http://pid.geoscience.gov.au/dataset/ga/101104. National total magnetic intensity map: http://pid.geoscience.gov.au/dataset/ga/89596

\subsection{Surficial deposits}

Figure 4 shows surface geology around the Tennant Creek ruptures. Eolian sand $\sim 2-10 \mathrm{~m}$ thick covers much of the area. Localised calcrete mounds $20-40 \mathrm{~m}$ in diameter form small hills $1-10 \mathrm{~m}$ high in the vicinity of Lake Surprise (Crone et al., 1992; Donnellan et al., 1998). Local ephemeral drainage flows into Lake Surprise during occasional large storms.

The Lake surprise scarps approximately coincide with the southern interpreted boundary of the Palparti paleo-valley (Bell et al., 2012). The Kunayungku scarp is developed entirely within the paleovalley. Borehole intersections indicate that silicified alluvial sediments within the paleovalley are up to 45 - 50 m thick (RN016003).

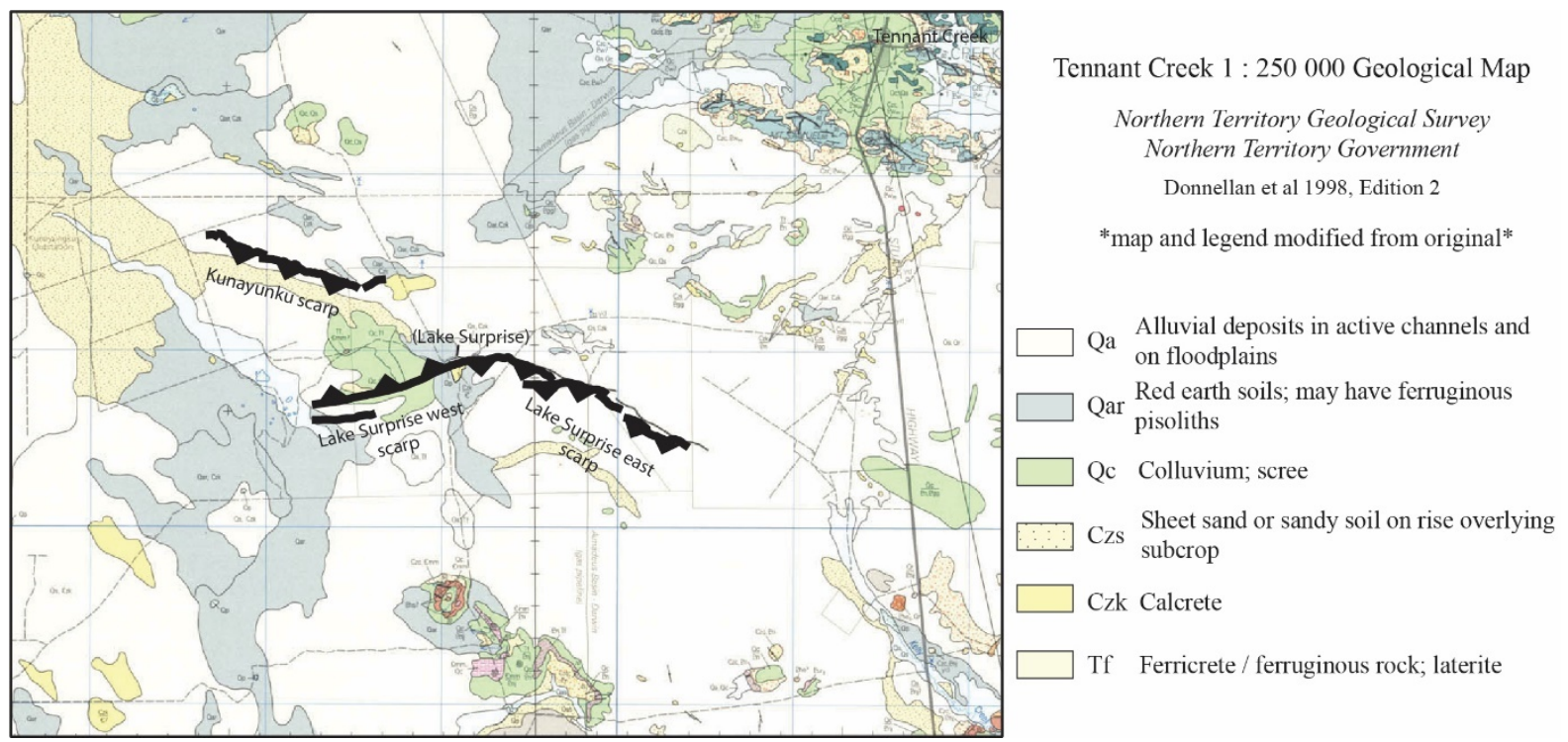

Figure 4. Crop of $1: 250000$ Tennant Creek geological map (Donnellan et al., 1998) with Tennant Creek scarps overlaid. Original map and legend available from:

https://geoscience.nt.gov.au/gemis/ntgsjspui/handle/1/81430. Used under creative commons from the Northern Territory of Australia (Northern Territory Geological Survey) 
151

\section{Seismology of the 1987 to 2019 Tennant Creek earthquake sequence}

\subsection{8 epicentre location and magnitude estimates}

The Tennant Creek earthquake sequence includes three distinct mainshocks $\left(\mathrm{M}_{\mathrm{w}} 6.3,6.4\right.$ and 6.6) that occurred within a 12 -hour period on the $22^{\text {nd }}$ January 1988 . Epicentral locations are $\sim 30 \mathrm{~km}$ west of the Warramunga Array, a 20-instrument seismic network setup in 1965, in what was assumed to be a seismically quiescent area, to monitor global nuclear weapons testing. Table 1 provides epicentre locations and magnitude estimates from published sources.

Bowman (1988) present relocated epicentre locations, but the coordinates of this work were not published until Bowman and Dewey (1991), and then again with slightly different longitude values in Crone et al. (1992). Bowman and Dewey (1991) describe relocation method for these epicentres as using joint-hypocentre determination. Alternate locations were published by Jones et al. (1991) (who use the Australian Seismological Centre locations), and Choy and Bowman (1990) who include the USGS (then NEIS) coordinates. McCaffrey (1989) used teleseismic long-period P and SH waves, and short-period $\mathrm{P}$ waves to compute locations, but did not publish coordinate values for these relocated events. The current Geoscience Australia (GA) online catalogue epicentres are the Jones et al. (1991) coordinates with one extra decimal place (slightly changing the location (Figure 5)). The NSHA18 catalogue (Allen et al., 2018b) reports epicentral locations from GG-Cat that are distal from the surface ruptures and thus considered to be inaccurate relative to the Bowman and Dewey (1991) locations (Mohammadi et al., 2019).

To reduce epicentre uncertainty, Bowman and Dewey, 1991 relocated the mainshocks using joint hypocentre determination, aftershocks distributions from temporary seismometer arrays (Bowman et al., 1990), and P-wave arrivals across the Warramunga array (Bowman, 1988). Bowman and Dewey (1991) report uncertainties of $\pm 1.0-1.1 \mathrm{~km}$ (longitude) and $\pm 2.6-2.8 \mathrm{~km}$ (latitude). Jones et al. (1991) report uncertainties of \pm 0.03 to 0.06 (longitude) and \pm 0.02 (latitude). It is unclear but assumed that these values refer to degrees of latitude and longitude not kilometres, as uncertainties of $20-60 \mathrm{~m}$ would be improbable given the instrumental distribution. The GA online catalogue uses the Jones et al. (1991) epicentre locations and reports uncertainties of $\pm 0.93-1.14 \mathrm{~km}$ (longitude) and \pm $1.64-1.96 \mathrm{~km}$ (latitude), which are assumed to represent the Jones et al. (1991) uncertainties.

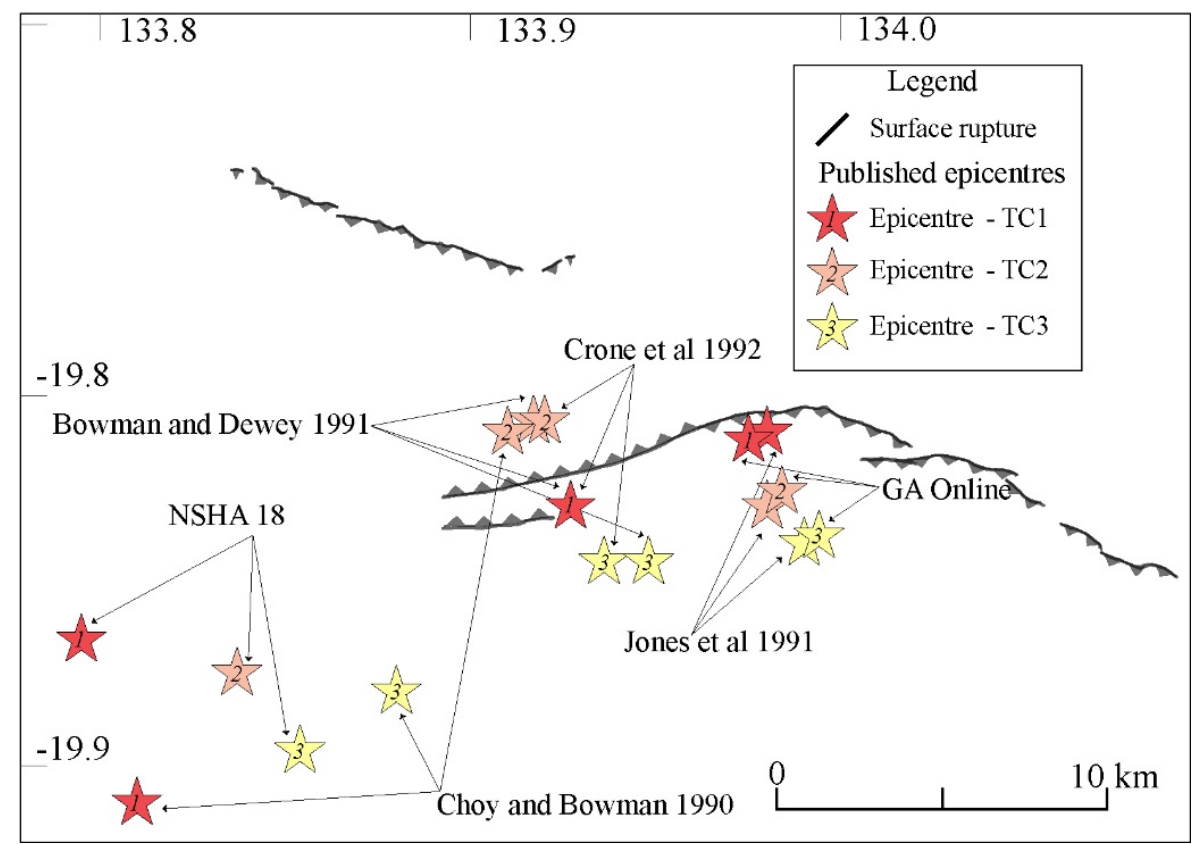

Figure 5: Published epicentre locations around the Tennant Creek 1988 surface ruptures 
This is a non-peer reviewed preprint submitted to EarthArXiv

180 Table 1: 1988 mainshock epicentre locations, depths, magnitudes

\begin{tabular}{|c|c|c|c|c|c|c|c|c|c|c|c|c|c|c|}
\hline Event & Reference & Agency & Latitude & $\begin{array}{c} \pm \\
(\mathbf{k m})\end{array}$ & Longitude & $\begin{array}{c} \pm \\
(\mathbf{k m})\end{array}$ & $\begin{array}{c}\text { Depth } \\
(\mathbf{k m})\end{array}$ & $\begin{array}{c} \pm \\
(\mathbf{k m})\end{array}$ & \multicolumn{2}{|c|}{ M1 } & \multicolumn{2}{|c|}{ M2 } & \multicolumn{2}{|c|}{ M3 } \\
\hline \multirow{6}{*}{$\mathrm{TC} 1$} & $\begin{array}{l}\text { Allen et al } \\
\text { (2018) }\end{array}$ & NSHA18 & -19.866 & & 133.795 & & 5 & & 6.27 & $\mathrm{Mw}$ & & & & \\
\hline & $\begin{array}{l}\text { Bowman and } \\
\text { Dewey } \\
(1991)\end{array}$ & USGS & -19.83 & 2.8 & 133.927 & 1 & 6.5 & & 6.1 & $\mathrm{Mb}$ & 6.3 & Ms & & \\
\hline & $\begin{array}{l}\text { Choy and } \\
\text { Bowman } \\
(1990)\end{array}$ & USGS & -19.91 & & 133.81 & & 6.5 & 1 & 6.1 & $\mathrm{Mb}$ & 6.3 & Ms & & \\
\hline & $\begin{array}{l}\text { Crone et al } \\
(1992)\end{array}$ & & -19.83 & & 133.927 & & 6.5 & & 6.1 & $\mathrm{Mb}$ & 6.3 & Ms & & \\
\hline & GA_Online & GA & -19.812 & 1.9616 & 133.975 & 1.1362 & 6 & 0.6264 & 6.1 & $\mathrm{Mb}$ & 6.3 & $\mathrm{ML}$ & 6.2 & Ms \\
\hline & $\begin{array}{l}\text { Jones et al } \\
\text { (1991) }\end{array}$ & $\begin{array}{l}\text { Aust. } \\
\text { seismo. } \\
\text { centre }\end{array}$ & -19.81 & 0.02 & 133.98 & 0.06 & 6 & 4 & 6.3 & Ms & 6.3 & ML & & \\
\hline \multirow{6}{*}{ TC2 } & $\begin{array}{l}\text { Allen et al } \\
\text { (2018) }\end{array}$ & NSHA18 & -19.875 & & 133.837 & & 3 & & 6.44 & $\mathrm{Mw}$ & & & & \\
\hline & $\begin{array}{l}\text { Bowman and } \\
\text { Dewey } \\
(1991)\end{array}$ & USGS & -19.807 & 2.7 & 133.917 & 1 & 3.5 & & 6.1 & $\mathrm{Mb}$ & 6.4 & Ms & & \\
\hline & $\begin{array}{l}\text { Choy and } \\
\text { Bowman } \\
(1990)\end{array}$ & USGS & -19.81 & & 133.91 & & 3.5 & 0.5 & 6.1 & $\mathrm{Mb}$ & 6.4 & Ms & & \\
\hline & $\begin{array}{l}\text { Crone et al } \\
(1992)\end{array}$ & & -19.807 & & 133.92 & & 3.5 & & 6.1 & $\mathrm{Mb}$ & 6.4 & Ms & & \\
\hline & GA_Online & GA & -19.826 & 1.7845 & 133.984 & 0.9798 & 4 & 0.2102 & 6.1 & $\mathrm{Mb}$ & 6.4 & $\mathrm{ML}$ & 6.3 & Ms \\
\hline & $\begin{array}{l}\text { Jones et al } \\
\text { (1991) }\end{array}$ & $\begin{array}{l}\text { Aust. } \\
\text { seismo. } \\
\text { centre }\end{array}$ & -19.83 & 0.02 & 133.98 & 0.05 & 4 & 3 & 6.4 & Ms & 6.4 & ML & & \\
\hline \multirow{6}{*}{$\mathrm{TC} 3$} & $\begin{array}{l}\text { Allen et al } \\
\text { (2018) }\end{array}$ & NSHA18 & -19.896 & & 133.854 & & 5 & & 6.58 & $\mathrm{Mw}$ & & & & \\
\hline & $\begin{array}{l}\text { Bowman and } \\
\text { Dewey } \\
(1991)\end{array}$ & USGS & -19.845 & 2.6 & 133.948 & 1.1 & 4.5 & & 6.5 & $\mathrm{Mb}$ & 6.7 & Ms & & \\
\hline & $\begin{array}{l}\text { Choy and } \\
\text { Bowman } \\
(1990)\end{array}$ & USGS & -19.88 & & 133.88 & & 4.5 & 0.5 & 6.5 & $\mathrm{Mb}$ & 6.3 & Ms & & \\
\hline & $\begin{array}{l}\text { Crone et al } \\
\text { (1992) }\end{array}$ & & -19.845 & & 133.936 & & 4.5 & & 6.5 & $\mathrm{Mb}$ & 6.7 & Ms & & \\
\hline & GA_Online & GA & -19.838 & 1.6378 & 133.994 & 0.9271 & 5 & 0.1816 & 6.5 & $\mathrm{Mb}$ & 6.7 & ML & 6.5 & Ms \\
\hline & $\begin{array}{l}\text { Jones et al } \\
\text { (1991) }\end{array}$ & $\begin{array}{l}\text { Aust. } \\
\text { seismo. } \\
\text { centre }\end{array}$ & -19.84 & 0.02 & 133.99 & 0.03 & 5 & 3 & 6.7 & Ms & 6.7 & ML & & \\
\hline
\end{tabular}


182 Bowman and Dewey (1991) (and subsequent authors) show TC1 between TC2 (to the west) and TC3

183 (to the east) (Figure 5). Bowman (1992) notes that the first two mainshocks have overlapping uncertainty bounds and this order is constrained by P-wave arrivals at the Warramunga array (Bowman, 1988). Other authors (Jones et al., 1991) show the epicentres occurring sequentially from west to east (Figure 5).

187 A gas pipeline offset by the Lake Surprise east scarp was found to be undamaged when inspected by a worker following the first mainshock (TC1). Some uncertainty exists as to when this inspection took place relative to the three events. Bowman (1988) describe the observation between the TC1 and TC3, while Jones et al. (1991) state that it was between TC1 and TC2. Some authors use this observation to directly relate the TC3 event to the Lake Surprise east scarp (Choy and Bowman, 1990) however based on varying descriptions, this observation only rules out the TC1 event.

McCaffrey (1989) discusses alternate scenarios where individual mainshocks may have ruptured multiple faults at once, with later mainshocks potentially re-rupturing faults. Or where the Lake Surprise west scarp is related to post-seismic failure of the hanging-wall, which seems unlikely given geodetic and seismic modelling published following this paper (Bowman, 1991; Choy and Bowman, 1990). Field observations (Bowman, 1991; Bowman and Jones, 1991; Crone et al., 1992; Machette et al., 1991), aftershocks (Bowman et al., 1990) and seismic modelling (Choy and Bowman, 1990) are interpreted to show that the Lake Surprise west scarp corresponds to a north-dipping fault, while the Kunayungku and Lake Surprise east scarps correspond to south-dipping faults.

Mohammadi et al. (2019) use Coulomb stress change modelling to assess the validity of published hypocentre locations and fault models from Choy and Bowman (1990), McCaffrey (1989), Leonard et al. (2002) (which uses the Jones et al. (1991) solutions), and Bowman (1991). Fault geometries are defined either from the source publication, or derived from the intraplate $\mathrm{M}_{\mathrm{w}}$ to fault area scaling relationships of Leonard (2014). The authors find that within the uncertainties of hypocentral location, all faults in all models have regions of positive coulomb stress changes from the previous rupture (using rupture sequences from the original publications). They prefer the data integrated fault model of Bowman (1991), with slightly modified fault parameters (within error of the original parameters) as the hypocentres from Choy and Bowman (1990) do not intersect with modelled faults from Bowman (1991).

\subsection{8 mainshock focal mechanisms}

212 Focal mechanisms for the three 1988 mainshocks were published by McCaffrey (1989), Jones et al. (1991), Choy and Bowman (1990), and the Global Centroid Moment Tensor catalog (GCMT) (Ekström et al., 2012) (Figure 6). McCaffrey (1989) uses least-squares inversion on short-period Pwave and long-period $\mathrm{P}$ - and $\mathrm{SH}$-waves to derive source parameters and focal mechanism. Jones et al. (1991) derive preliminary focal mechanisms from long-period P-wave arrivals, while Choy and Bowman (1990) use broadband body waves rather than long-period data to derive their mechanisms. A summary of mainshock focal mechanisms is presented in Fig. 12 of Bowman (1992).

Focal mechanisms were also derived by GCMT for a $5.4 \mathrm{M}_{\mathrm{L}}$ earthquake in January 1987 that preceded the mainshock sequence by a year (Ekström et al., 2012), and for the largest aftershock on the 22nd Jan 1988 by Choy and Bowman (1990) and Jones et al. (1991). Leonard et al. (2002) collates mechanisms for fore-, main- and aftershocks from Jones et al. (1991) and GCMT, but not Choy and Bowman (1990) or McCaffrey (1989). Mohammadi et al. (2019) use focal mechanisms from the 1987 foreshock and original publications (Choy and Bowman, 1990; Jones et al., 1991; McCaffrey, 1989 ) in their Coulomb stress change models. 
This is a non-peer reviewed preprint submitted to EarthArXiv

$\begin{array}{lll}\text { Tennant Creek } 1 & \text { Tennant Creek } 2 & \text { Tennant Creek } 3\end{array}$
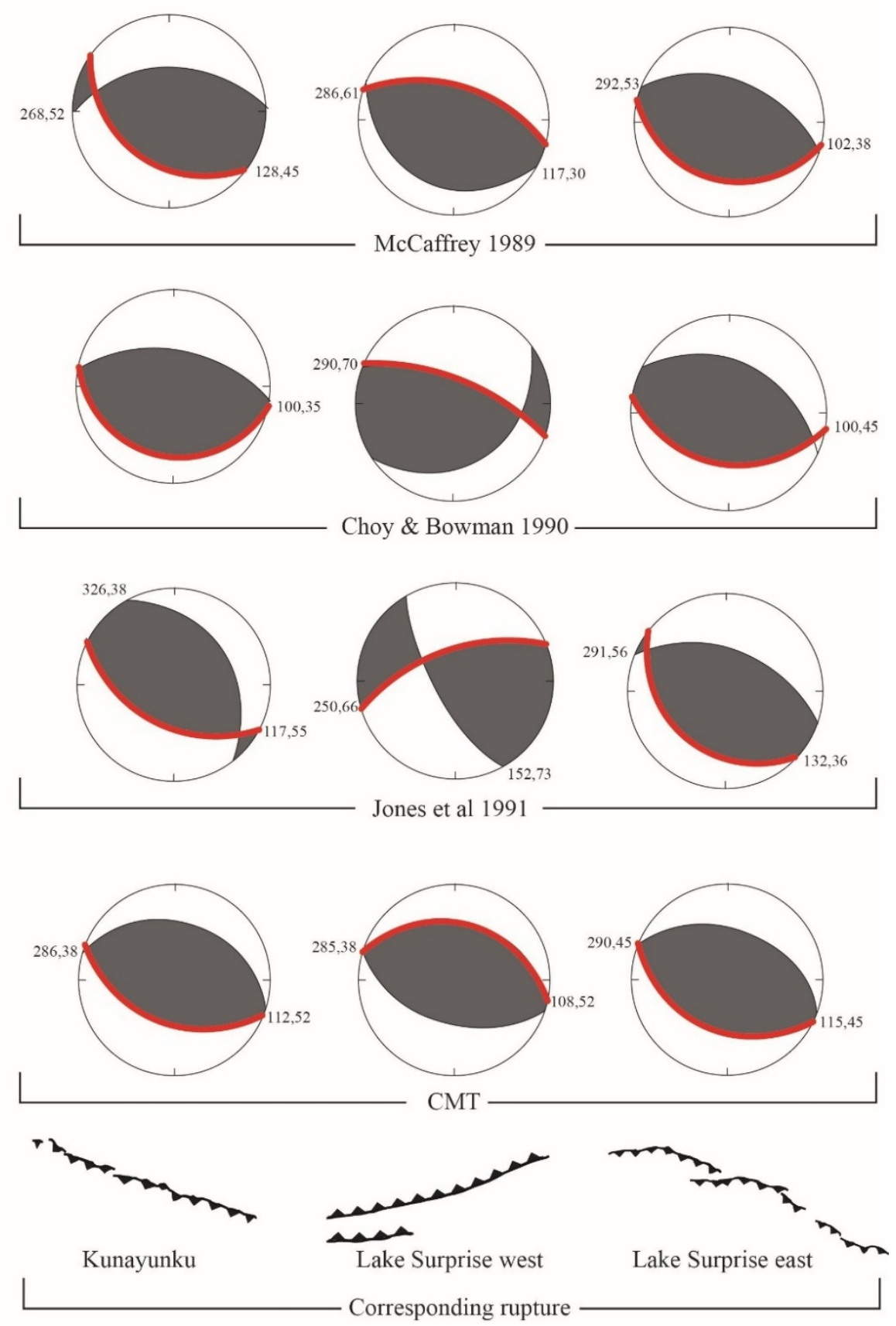

Figure 6: Published focal mechanism and simplified scarp maps. Red lines show the preferred plane of rupture based on the work of (Choy and Bowman, 1990)

227 Focal mechanisms for TC1 are predominately thrust mechanisms with WNW-ESE striking planes in all publications. Surface rupture, aftershock depths and waveform data are interpreted to suggest this event ruptured the Kunayungku scarp, on a south-dipping plane (Bowman, 1992; Choy and Bowman, 1990). The south-dipping plane is consistently steeper on all solutions at $50-55^{\circ}$.

231 Focal mechanisms for TC2 are the most variable across different publications. Bowman (1992) suggests this may be because rupture involved complex faulting on conjugate or non-planar fault 
surfaces. McCaffrey (1989) interprets TC2 to have ruptured either / both of the Kunayungku and Lake Surprise west scarps, while Jones et al. (1991) suggest TC2 is responsible only for the Lake Surprise west scarp on a north-dipping plane. Surface observations and seismological data are interpreted by Choy and Bowman (1990) to suggest that TC2 ruptured the Lake Surprise west scarp on a northdipping plane.

The McCaffrey (1989) and CMT solutions for TC2 provide a pure thrust mechanism with a WNWESE trend, with north planes dipping at $61^{\circ}$ and $52^{\circ}$ respectively. The Jones et al. (1991) solution shows dominantly strike-slip movement, with dextral movement on the north-dipping plane which trends NW. Choy and Bowman (1990) preferred an interpretation that TC2 was associated with three sub-events of moment release along faults with variable geometries. The first two events of this model do not reach the surface and have mechanisms similar to the McCaffrey (1989) solution. The third sub-event is identified as the north-dipping fault responsible for the Lake Surprise west scarp. The second sub-event in this series is considered the dominant solution, with highest seismic moment release on a thrust with a relatively large strike slip component. The third minor solution is largely thrust with a NE-SW trend and minor dextral movement on the north-dipping plane (fig. 4 of Choy and Bowman (1990) shows mechanisms for these two subevents) (Bowman, 1991; Bowman et al., 1990; Choy and Bowman, 1990). Mohammadi et al. (2019) split TC2 into the two potential sub-event geometries from the Choy and Bowman (1990) solution for their Coulomb stress change modelling, and find that both models for TC2 are consistent with positive Coulomb stress changes from the preceding events.

Focal mechanisms for TC3 are the most consistent across publications, showing an almost pure reverse mechanism on a WNW - ESE trending plane. Scientific consensus is that this event ruptured the Lake Surprise east scarp on a south-dipping fault (Bowman, 1992; Choy and Bowman, 1990; Jones et al., 1991; McCaffrey, 1989)(Bowman, 1988). North-dipping planes range from dips of 36$45^{\circ}$.

\subsection{Depth estimates of 1988 mainshocks}

Hypocentral depths are estimated from a variety of sources including primary seismological data, aftershock distributions and focal mechanisms. Jones et al. (1991) report depths from the USGS of $6 \pm$ $4 \mathrm{~km}, 4 \pm 3 \mathrm{~km}$ and $4 \pm 3 \mathrm{~km}$ for TC1, TC2 and TC3 respectively. These depths are included in the current online Geoscience Australia catalogue, though the current USGS online catalogue reports 5 $\mathrm{km}$ depths for all events (both accessed 23/07/2019).

Choy and Bowman (1990) prefer a hypocentral depth of $6.5 \pm 1.0 \mathrm{~km}$ for TC1, $3 \pm 0.5 \mathrm{~km}$ for TC2, and $4.5 \pm 0.5 \mathrm{~km}$ for TC3 based on analysis of teleseismic broadband P-wave inversions. Depth estimates of Choy and Bowman (1990) are within error of planes delineated by well-constrained aftershock depths (Bowman et al., 1990). These place TC1 at $6-8 \mathrm{~km}$ depth on a south-dipping plane, TC2 at $2-4 \mathrm{~km}$ depth on a north-dipping plane, and TC3 at $3-5 \mathrm{~km}$ depth on a south-dipping plane (e.g. Figure 9 in Bowman et al. (1990)).

McCaffrey (1989) find centroid best-fit depths of $2.7 \pm 2.6 \mathrm{~km}, 3.0 \pm 1.3 \mathrm{~km}$ and $4.2 \pm 1.9 \mathrm{~km}$ for $\mathrm{TC} 1, \mathrm{TC} 2$ and TC3 respectively based on teleseismic waveform inversion, with all centroids constrained to $<6 \mathrm{~km}$. Attempts to model centroids down to $9 \mathrm{~km}$ depth based on aftershock zones (Bowman, 1988) resulted in a poorer fit.

\section{4 $\mathrm{Bi} /$ Uni lateral rupture}

McCaffrey (1989) propose that short period P-wave data show north-west unilateral propagating rupture for TC1. They suggest that this supports TC1 rupture of the south-dipping Kunayungku fault. They describe the TC2 source-time function (related to seismic moment) as small for the first $3 \mathrm{sec}$ and doubling in the next $3 \mathrm{sec}$, relating to a sudden doubling of either fault slip or fault area. This is 
279 interpreted to show bilateral rupture initiating between the Kunayungku and Lake Surprise west 280 scarps, with a sudden increase in slip after initiation allowing for rupture to the surface along one or 281 both of those scarps. McCaffrey (1989) do not comment on TC3 rupture propagation.

282 Jones et al. (1991) support unilateral NW rupture propagation for TC1. They suggest that TC2 initiated at the midpoint of the Lake Surprise scarps and ruptured bilaterally onto both limbs of the Lake Surprise fault, on faults with opposing geometries. Finally, they suggest TC3 initiated on a SW dipping fault to cause the Lake Surprise east scarp, and based on the magnitude, may have re-ruptured the entire fault trace (including Kunayungku and Lake Surprise west) implying bilateral rupture propagation. It is unclear what methods were used to derive these rupture propagation directions.

Choy and Bowman (1990) use first motion P-wave complexity to infer rupture complexity and direction for all three mainshocks. They suggest that TC1 initiated at a depth of $6.5 \mathrm{~km}$ at the location of previous foreshock seismicity and propagated towards the NW to rupture the surface at the Kunayungku scarp. Waveforms for TC2 was complex and had no observable directivity to rupture propagation, it is inferred to have initiated in the same vicinity as TC1 and ruptured in a conjugate sense to the Kunayungku fault, forming the Western Lake Surprise scarp. The final event, TC3, is interpreted to have initiated at $4.5 \mathrm{~km}$ depth east of the other events, and propagated in a SE direction to rupture the surface along the Eastern Lake Surprise scarp. Choy and Bowman (1990) present the most comprehensive analysis of seismological and surface observations to derive their preferred rupture propagation directions.

\subsection{Foreshocks to the 1988 mainshocks}

Bowman (1997) presents data to suggest seismicity was anomalously high in the year preceding the mainshocks. This includes six $\mathrm{M}_{\mathrm{L}} 4.0$ - 5.0 events 12 months prior, and 1100 small events. The nearby Warramunga Array had been operational since 1965, with no seismic activity recorded in the vicinity of the surface ruptures prior to 1981 (from personal communications with site seismologists (Bowman and Yong, 1997)). Based on seismicity rates from 1981 - 1986 compared to 1986 - 1988, Bowman (1997) argues that Tennant Creek experienced precursor seismicity in the immediate vicinity of the 1988 mainshocks. A lack of national instrumentation prior to 1980 may have affected catalogue completeness for events $\mathrm{M}_{\mathrm{L}}<2.0$ (Leonard, 2008), but the location of the Warramunga Array proximal to this region suggests minimal seismicity prior to 1986 .

Following four earthquakes of $\mathrm{M}_{\mathrm{L}} 4.9$ - 5.4 from 5 - 9th January 1987 (12 months prior to the mainshocks), three temporary seismometers were installed in the area for two months, with 116 events recorded, and 50 located with high accuracy (Bouniot et al., 1990). Based on the temporal decay of total seismic moment release and number of earthquakes, the authors conclude precursor seismicity gave no indication of the three mainshocks to come. The 1987 seismicity is noted to lie in the 'gap' between the Lake Surprise west and Kunayungku ruptures (Bouniot et al., 1990) which some authors consider coincident with the location of TC1 (Jones et al., 1991). Bowman and Dewey (1991) relocate as many 1987 events as possible using joint hypocentre determination, and consider the focal depths not sufficiently precise to constrain if they occurred on the fault that eventually ruptured in TC1. A single foreshock of MD 3.6 is reported by some authors 6 minutes prior to the first mainshock (Bowman, 1992, 1988; Bowman and Dewey, 1991).

Mohammadi et al. (2019) use Coulomb stress change modelling to test whether the largest 1987 foreshock $\left(\mathrm{M}_{\mathrm{b}} 5.2\right.$ magnitude from Bowman and Dewey (1991)) produced stress changes that contributed to the rupture of the TC1 fault (as modelled in a variety of original sources (Bowman, 1991; Choy and Bowman, 1990; Jones et al., 1991; McCaffrey, 1989)). They suggest that dynamic stress changes from the foreshock are unlikely to have imparted the primary control on the TC1 event given the time lag between these events, but that static stress changes are consistent with advancement of TC1 towards failure. They note that their modelling does not account for potential post-seismic 
stress changes (visco-elastic, afterslip or poroelastic rebound) between the foreshock and TC1. While this supports the assertion of Bowman (1997) that precursor seismicity was causally related to the eventual 1988 events, it does not provide a potential forecast mechanism for future seismicity given the faults that failed in 1988 were unknown prior to rupture.

\subsection{Aftershocks following the 1988 mainshocks}

Over 20,000 aftershocks were recorded from 1988 - 1992 (Bowman, 1992). The largest of these include $a \mathrm{M}_{\mathrm{b}} 5.8$ aftershock recorded nine hours after the third mainshock, a $\mathrm{M}_{\mathrm{b}} 5.5$ seven days later, and $\mathrm{a} \mathrm{M}_{\mathrm{b}} 5.2$ eight months later. A temporary seismometer array was installed two days after the mainshock and operated for sixteen months until May 1988 (details in Table 1 of Bowman et al. (1990)). Aftershocks locations in the year following the mainshocks concentrate south of the Kunayungku and Lake Surprise east scarps, and north of the Lake Surprise west scarp. These are used as supportive evidence, along with a variety of geological and seismological data, to suggest the three mainshocks ruptured three conjugate faults (Bowman, 1991). Estimates for uncertainties on these locations range from $1.3-2.7 \mathrm{~km}$. Bouniot et al. (1990) consider their 1987 seismicity to have uncertainties $< \pm 2 \mathrm{~km}$. Bowman and Dewey (1991) present all relocated foreshock, mainshock and aftershock epicentres with $< \pm 8 \mathrm{~km}$ uncertainty, with some having uncertainties down to $\pm 1 \mathrm{~km}$.

The recently published NSHA18 catalogue (Allen et al., 2018b) (which includes revised $\mathrm{M}_{\mathrm{w}}$ values for all events) shows four Mw $>5.0$ aftershocks between 1990 and 2017 (the catalogue cut-off year) within a $50 \mathrm{~km}$ radius of the 1988 mainshocks (Figure 7). It also includes $28 \mathrm{M}_{\mathrm{w}} 3.0-4.0$ aftershocks within a $100 \mathrm{~km}$ radius, with the most recent in 2011.

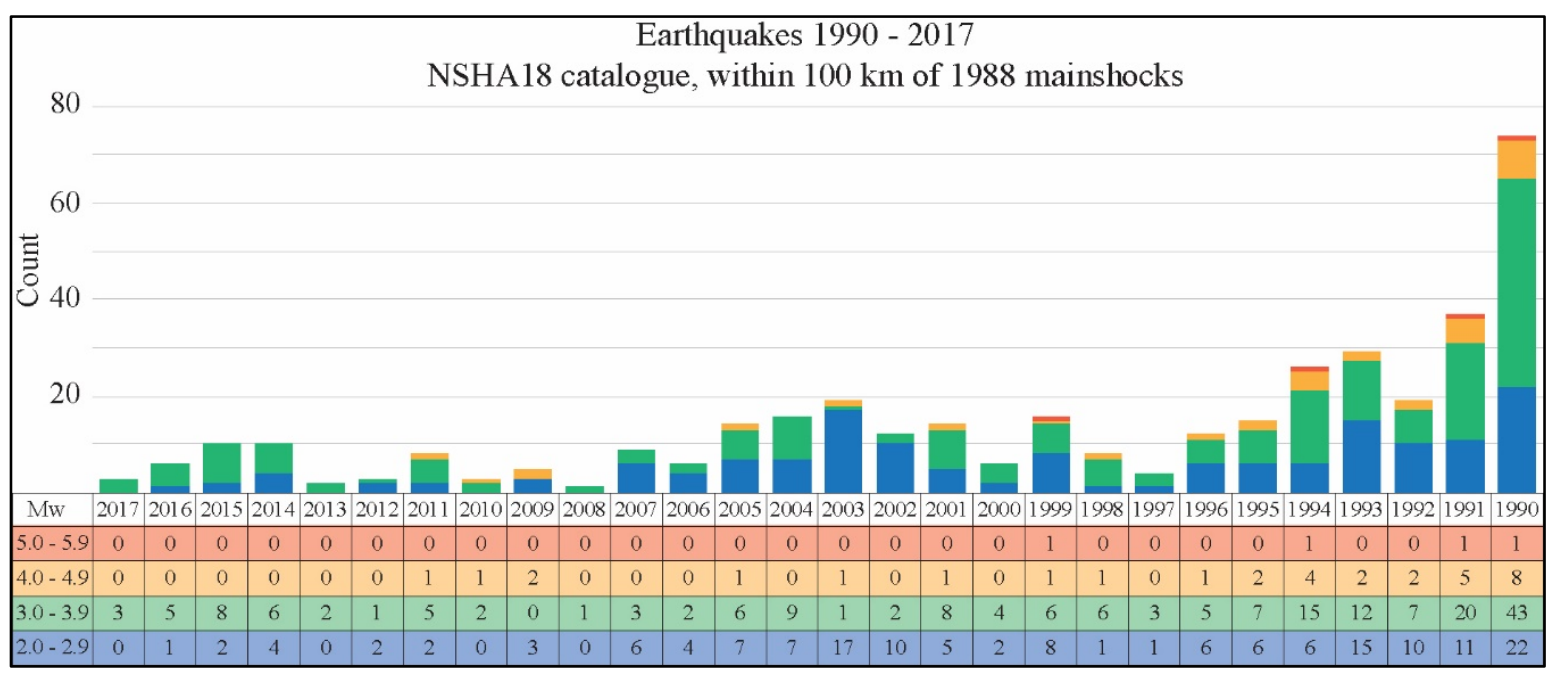

Figure 7: Count of aftershocks per year per magnitude range from the NSHA 18 catalogue (Allen et al., 2018b), 1990 to 2017 (the catalogue cut-off year)

\subsection{Seismology, InSAR fault modelling and Coulomb stress modelling of the $2019 M_{w} 5.0$ aftershock}

On the $1^{\text {st }}$ August 2019, a $\mathrm{M}_{\mathrm{w}} 5.0\left(\mathrm{M}_{\mathrm{b}} 5.4 \mathrm{USGS}, \mathrm{M}_{\mathrm{L}} 5.3 \mathrm{GA}\right)$ aftershock occurred, the largest since 1999, and has since been followed by five $\mathrm{M}_{\mathrm{L}} 2.5-3.6$ events (up to $20^{\text {th }}$ August 2019, Geoscience Australia online catalogue).

The USGS epicentre for the 2019 event is located on the eastern end of the 1988 Kunayungku scarp, while the Geoscience Australia epicentre is $\sim 14.5 \mathrm{~km}$ west of the Lake Surprise west scarp. A third epicentre from GFZ-Potsdam is located $\sim 10 \mathrm{~km}$ south of the GA epicentre (location details Table 2). 
355 Depth estimates are all set to $10 \mathrm{~km}$, as there are no instruments in the national network close enough 356 to derive an accurate hypocentral depth.

357 Table 2: Epicentre locations, depth and magnitude estimates for the 2019 aftershock

\begin{tabular}{|l|l|l|l|l|l|l|ll|ll|l|}
\hline Agency & Latitude & $\pm(\mathrm{km})$ & Longitude & $\pm(\mathrm{km})$ & $\begin{array}{l}\text { Depth } \\
(\mathrm{km})\end{array}$ & $\pm(\mathrm{km})$ & M1 & M2 & M3 \\
\hline GFZ & -19.91 & & 133.78 & & 10 & & 5 & $\mathrm{Mw}$ & & & \\
\hline USGS & -19.765 & 5.2 & 133.916 & 5.2 & 10 & 1.9 & 5.4 & $\mathrm{Mb}$ & 5.0 & $\mathrm{Mww}$ & \\
\hline GA & -19.8145 & 4.46 & 133.7608 & 3.22 & 10 & 0 & 5.3 & $\mathrm{ML}$ & 5.0 & $\mathrm{Mw}$ & 5.2 \\
\hline
\end{tabular}

358

359 Three focal mechanisms have been published (GA, USGS and GFZ-Potsdam, Figure 8, Table 3). All

360 solutions are consistent with a NW-SE striking reverse fault. The GA solution shows a steeper dip

$361\left(67^{\circ}\right)$ for the south-west dipping plane, while the USGS south-west dipping plane is the shallower

362 solution, with a dip of $32^{\circ}$. The GFZ-Potsdam solution shows similar $\sim 45^{\circ}$ dips for both planes, and

363 no sense of lateral movement.

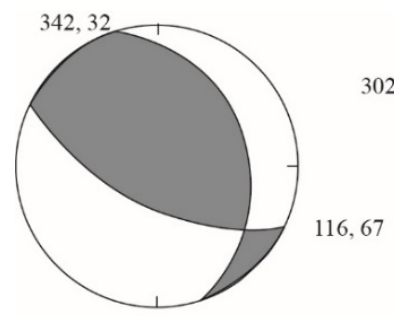

GA

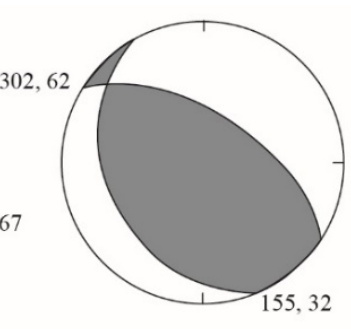

USGS

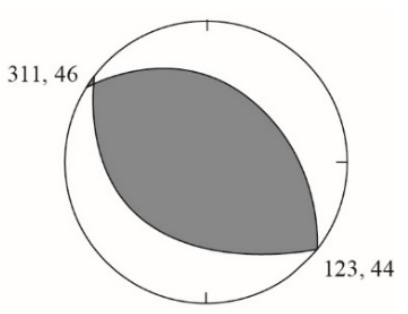

GFZ-Potsdam

Figure 8: Published focal mechanisms for the $1^{\text {st }}$ August $2019 M_{w} 5.0$ aftershock

364 Preliminary results of Coulomb stress modelling for the 1988 TC3 event show that the 2019

365 aftershock occurred in a positive ( $+>0.1$ bar) stress lobe from the 1988 event (Figure 9). Future

366 models will be added to this manuscript when they become available, including investigating how the 3671988 TC1, TC2 and TC3 events relate to the 2019 InSAR fault models.

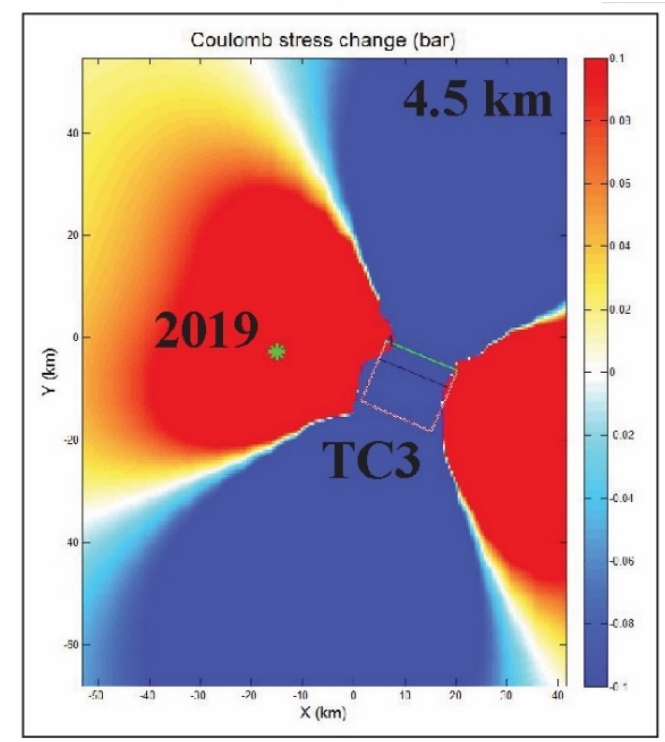

Figure 9: Preliminary Coulomb stress model showing 1988 TC3 stress lobes and the location of the 2019 aftershock at $4.5 \mathrm{~km}$ depth, showing the GA 2019 epicentre in the positive lobe of Coulomb stress change. Future work will explore Coulomb stress changes for the 2019 event InSAR fault models 
InSAR interferogram results (from Sentinel-1 descending pair) suggest the 2019 event occurred on a blind thrust $\sim 5 \mathrm{~km}$ west of the Lake Surprise west scarp. Unwrapped interferogram results show

$370 \quad 0.03 \mathrm{~m}$ offset in the InSAR line-of-sight. Interferogram contours are elongated in a NW-SE direction 371 and do not overlap within the uncertainty bounds of any published epicentre locations. This may

372 relate to epistemic uncertainties not captured in the published epicentre locations (e.g. differences in 373 velocity models), or suggest that the earthquake initiated within epicentre uncertainty bounds, and 374 ruptured upwards and/or uni-laterally towards the location of interferogram contours.

375 Two sets of InSAR fault modelling have been completed for this event (Table 3), both finding a best376 fit solution for the south-west dipping plane (Figure 10, Figure 11), depth to the top of the fault 377 within 1.16 to $2 \mathrm{~km}$, and depth to the bottom of the fault within 2.4 to $3.4 \mathrm{~km}$. These fault models 378 support shallow rupture along a $40-50^{\circ}$ south-west dipping blind fault.

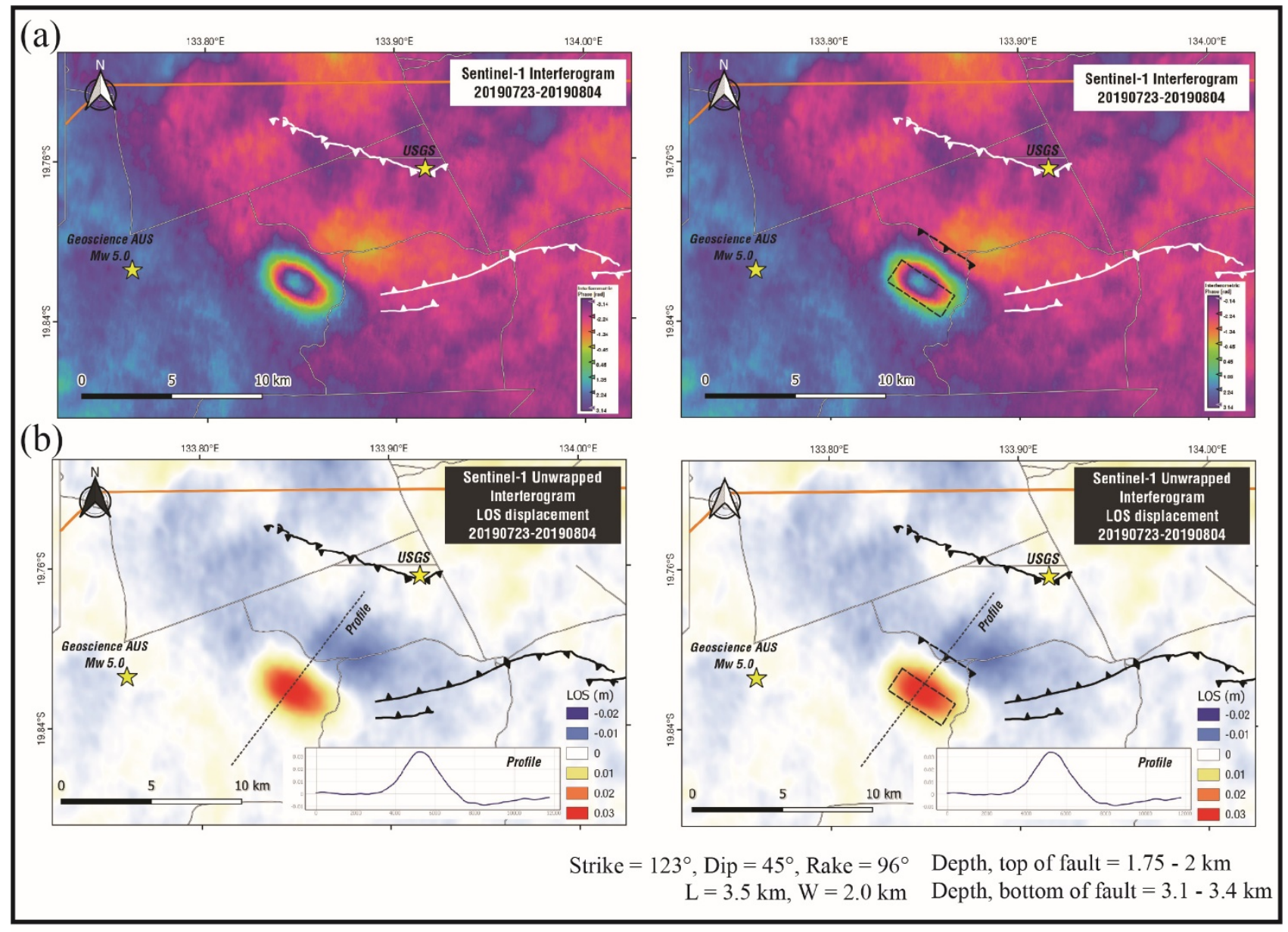

Figure 10: (a) InSAR interferogram from Sentinel-1 descending pairs (b) Unwrapped interferogram LOS displacement map, second panel in (a) and (b) shows best-fit fault model location on a south-west dipping fault (fault plane parameters at bottom of figure and in Table 3) 
This is a non-peer reviewed preprint submitted to EarthArXiv

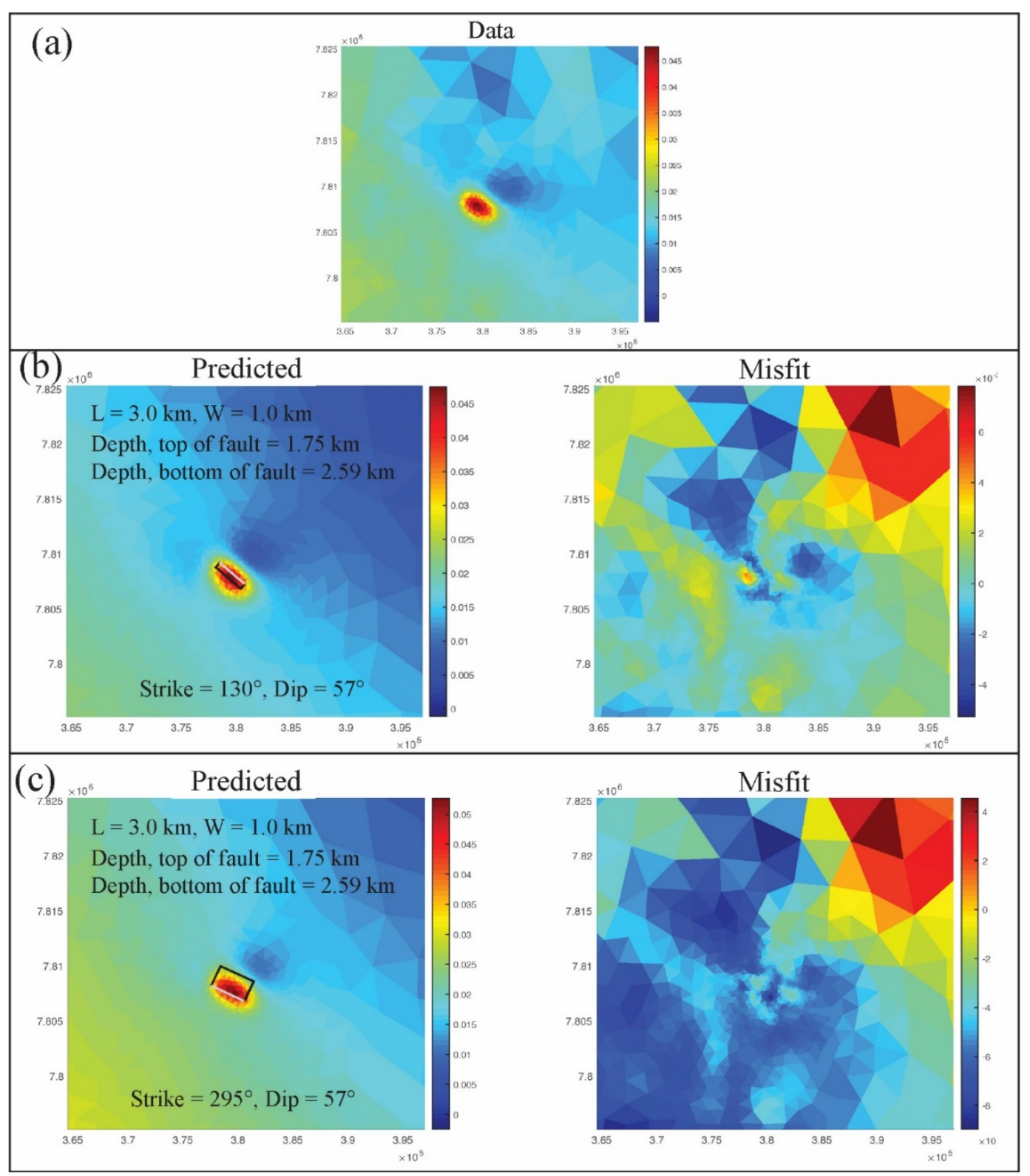

Figure 11: InSAR fault models for the $1^{\text {st }}$ August $2019 M_{w} 5.0$ aftershock (a) Original InSAR data (b) predicted model for south-west dipping fault plane and misfit (c) predicted model for north-east dipping fault plane and misfit

382 Table 3: Centroid moment focal mechanism and InSAR fault model solutions

\begin{tabular}{|l|l|l|l|l|l|l|l|l|l|l|l|}
\hline & \multicolumn{3}{|c|}{ Nodal plane 1 } & \multicolumn{3}{c|}{ Nodal plane 2 } & \multicolumn{5}{c|}{ InSAR Fault model } \\
\hline \multicolumn{1}{|c|}{ Agency } & Strike & Dip & Rake & Strike & Dip & Rake & $\begin{array}{c}\text { Length } \\
(\mathrm{km})\end{array}$ & $\begin{array}{c}\text { Width } \\
(\mathrm{km})\end{array}$ & $\begin{array}{c}\text { Slip } \\
(\mathrm{m})\end{array}$ & $\begin{array}{c}\text { Depth } \\
\text { to top }\end{array}$ & $\begin{array}{c}\text { Depth to } \\
\text { bottom }\end{array}$ \\
\hline GFZ & 132 & 44 & 84 & 311 & 46 & 96 & & & & & \\
\hline USGS & 155 & 32 & 119 & 302 & 62 & 73 & & & & & \\
\hline GA & 116 & 67 & 68 & 342 & 32 & 132 & & & & & \\
\hline S. Valkaniotis & 123 & 45 & 96 & & & & 3.5 & 2 & 0.2 & $1.7-2$ & $3.1-3.4$ \\
\hline W. Barnhart & 295 & 32 & & & & & 3.3 & 2.3 & & 1.16 & 2.4 \\
\hline W. Barnhart & 130 & 57 & & & & & 3 & 1 & & 1.75 & 2.59 \\
\hline
\end{tabular}




\section{Surface observations of the 1988 Tennant Creek surface ruptures}

\subsection{Authors / map quality}

The 1988 Tennant Creek surface ruptures occurred predominately on pastoral land accessible via the Stuart Highway, $35 \mathrm{~km}$ south west of Tennant Creek township. Bowman et al. (1988) presented the first map of the Tennant Creek scarps in an AGU abstract, describing two scarps divided into three segments, with a $35 \mathrm{~km}$ total length. Denham (1988) and Bowman (1988) provide the maps, but a comprehensive description of the rupture was not published until Bowman (1991). This paper presents rupture morphology and topographic cross sections obtained through surveying along and across the ruptures (Figure 12, Figure 16). Crone et al. (1992) provide comprehensive descriptions for surface observations of the ruptures, and trenches excavation across the ruptures.

Plate 1 of Crone et al. (1992) presents a map of the scarp at 1:50 000 scale with insets of mapping across the rupture at their trench locations 1:500 scale. Most subsequent work on the Tennant Creek rupture used simplified traces of the fault scarp mapped at 1:50,000, derived from Plate 1 of Crone et al. (1992). The rupture trace from this map is reproduced in the GA Neotectonics Features database (Clark et al., 2012). Sections of the rupture are visible in Google (C CNES/Airbus, Map data) and Bing satellite imagery (C DigitalGlobe, HERE, Microsoft), though they do not always align with the digitised rupture due to simplification of rupture morphology in the original map (Crone et al., 1992), and datum transformation errors.

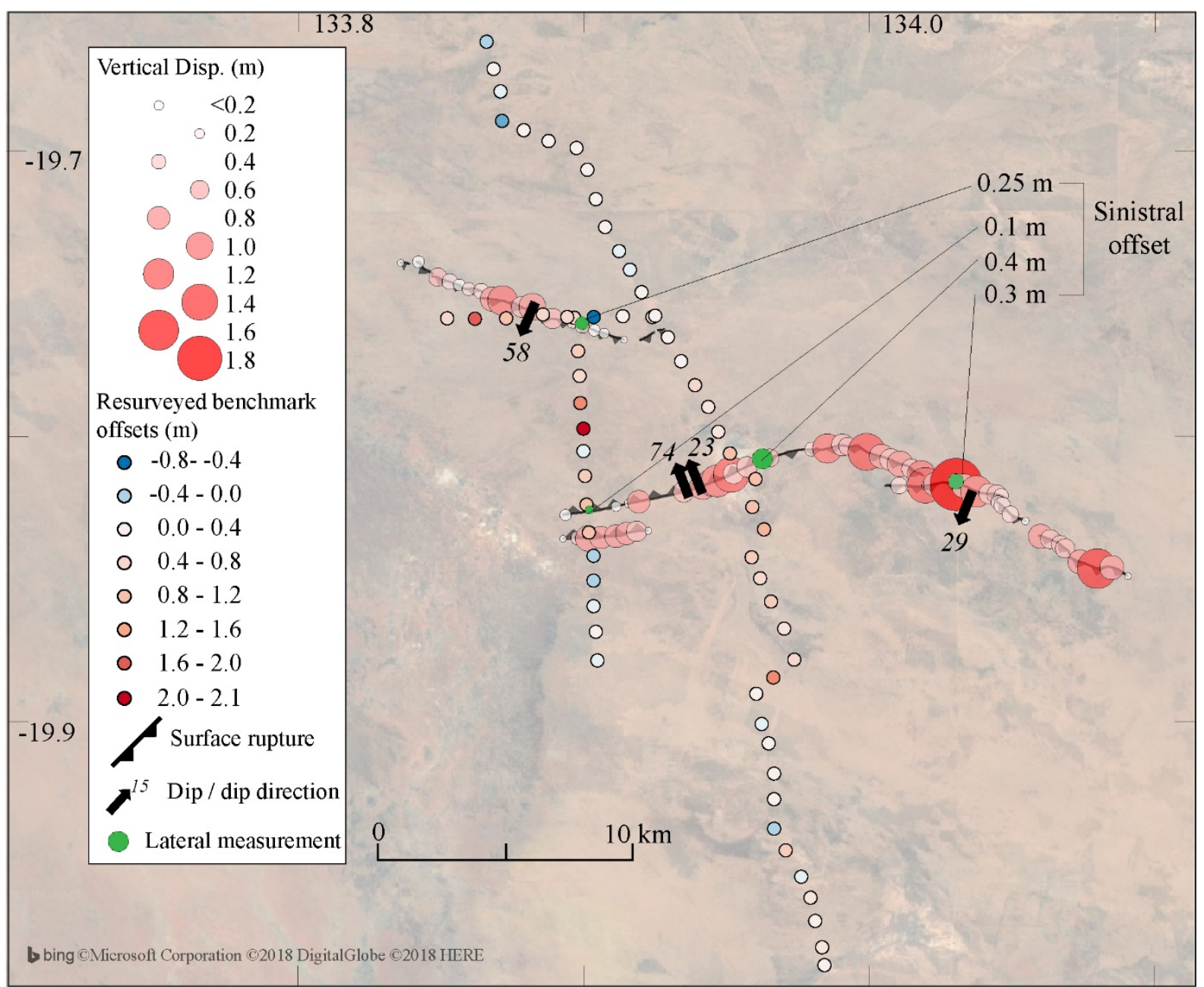

Figure 12: Map of the Tennant Creek scarps showing measured displacements along the rupture (Crone et al., 1992), resurveyed benchmarks and temporary benchmarks across the area (Bowman, 1991), and available dip measurements (Crone et al., 1992). 
402

403

404

405

406

407

The rupture is also imaged using 1988 pre- and post- earthquake Landsat 5TM data (Figure 13), created using the normalized difference (Raster2-Raster1/Raster2+Raster1) of Band 3 of the Landsat data. Source imagery has low resolution $(<30 \mathrm{~m}$ pixel size) but this method captures surface changes where deformation is high enough to dominate the spectral signal of the pixel, or wide enough to become visible. Kunayungku and Lake Surprise East ruptures are visible in the normalized difference product (dark lineaments on Fig 13).
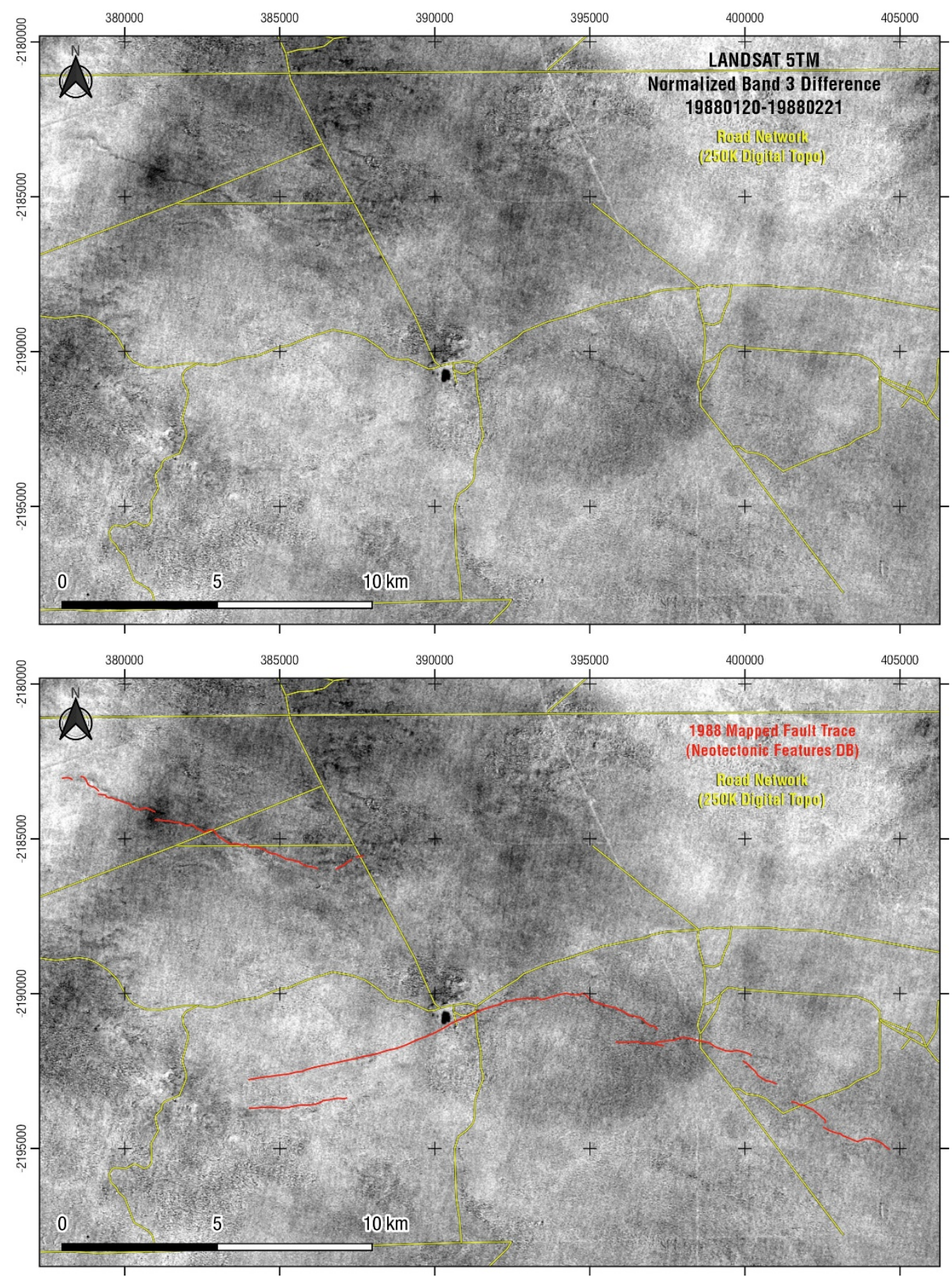

Figure 13: Imaging of the 1988 surface ruptures with historic Landsat data. Road network as yellow lines, with mapped 1988 surface rupture traces (red) for comparison. 
The Kunayungku scarp is linear and $10.2 \mathrm{~km}$ long (table 2, Crone et al. (1992)) (Figure 14b). The 1:50,000 map shows a minor step in the rupture of $<500 \mathrm{~m}$ width.

413 The published length of the Lake Surprise east scarp is $16 \mathrm{~km}$ (table 2, Crone et al. (1992)) (Figure 414 14b). The scarp is concave relative to the hanging-wall of this scarp (to the south) (Plate 1, Crone et al. (1992)). Two step overs in the scarp have overlaps of $1.5 \mathrm{~km}$ and $0.1 \mathrm{~km}$, while the two breaks have distances of 0.1 and $0.7 \mathrm{~km}$ between scarp segments. Maps of the Tennant Creek ruptures variably simplify these segments into 2 - 5 segments, or a single rupture (Figure 14b).

The published length of the Lake Surprise west scarp is $6.7 \mathrm{~km}$ (table 2, Crone et al. (1992)) (Figure $14 \mathrm{~b}$ ). The scarp is fairly straight, with a very slight concavity relative to the hanging-wall (to the north). A second scarp with published length of $3.1 \mathrm{~km}$ is mapped on the footwall $\sim 1 \mathrm{~km}$ away from the main trace of the western Lake Surprise scarp with the same strike and dip (table 2, Crone et al. (1992)) (Figure 14). Authors vary on whether they include this section of scarp within the total length of the Tennant Creek rupture (e.g. Figure 14b).

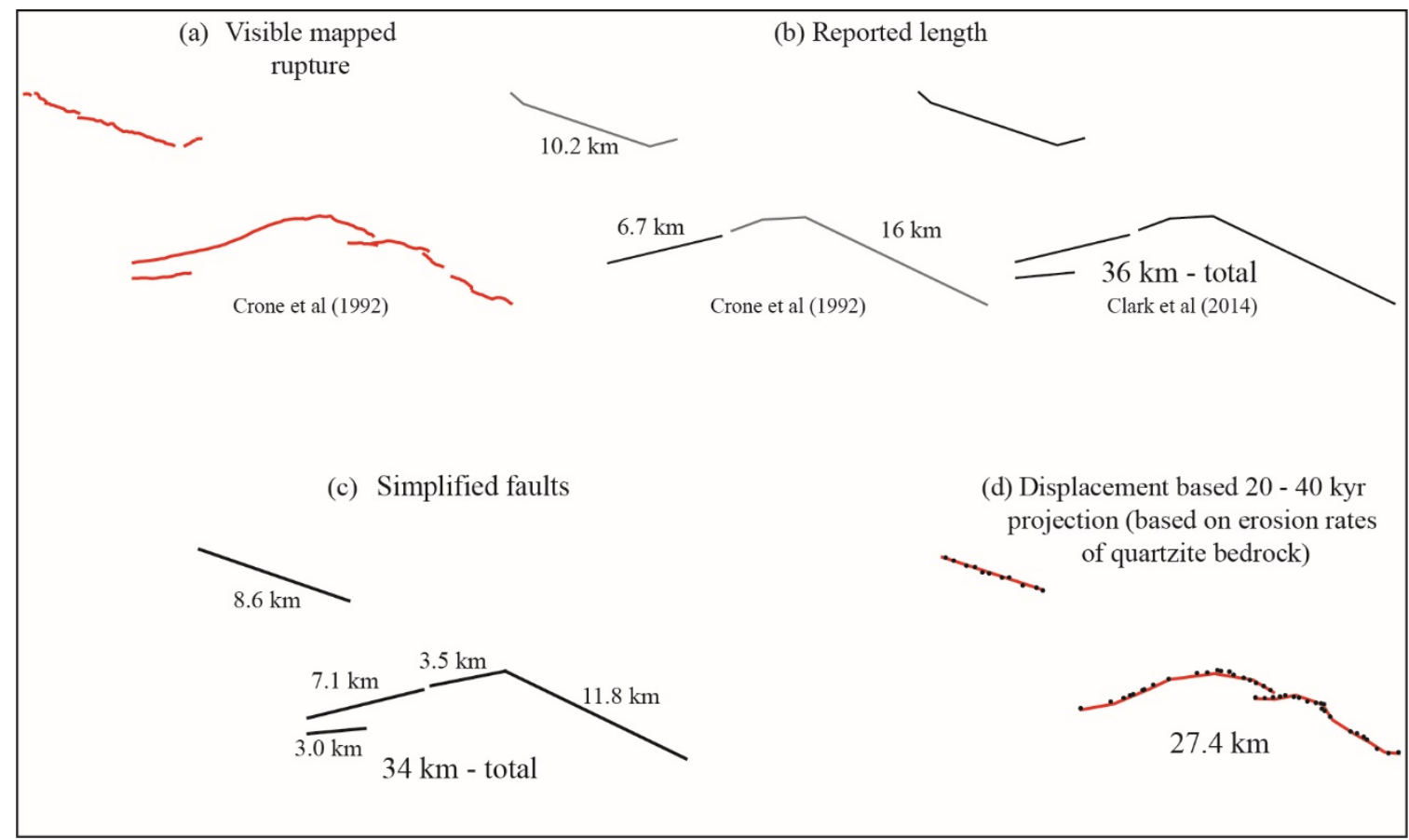

Figure 14: Various published and modelled length measurements of the Tennant Creek ruptures

The Tennant Creek rupture has been treated by multiple authors as a single rupture length for fault scaling relationships (Biasi and Wesnousky, 2017, 2016; Clark et al., 2014; Johnston et al., 1994; Wesnousky, 2008) and hazard mapping (Allen et al., 2018a) as opposed to three separate earthquakes and associated ruptures (Boncio et al., 2018; Leonard, 2010; Moss and Ross, 2011; Wells and Coppersmith, 1994). Clark et al. (2014) prefer a single combined rupture length of $36 \mathrm{~km}$ (Figure $14 \mathrm{~b}$ ) and single mainshock as in the absence of instrumental or recorded data it would not be possible to determine that the ruptures were related to three events.

Figure $14 \mathrm{~b}$ shows various measures of length along the Meckering scarp including the individual scarp lengths reported by (Crone et al., 1992), quoted in subsequent publications, and the scarps counted in the combined length used by Clark et al. (2014). The Crone et al. (1992) lengths does not include the footwall scarp associated with the Lake Surprise west rupture, though this scarp has length for the Lake Surprise west scarp (Figure 14c). 
438 Figure 14c simplifies ruptures to straight traces and defines distinct faults where mapped primary

439 rupture has gaps $/$ steps $>1 \mathrm{~km}$ and/or where strike changes by $>20^{\circ}$ for distances $>1 \mathrm{~km}$ (e.g.

440 (Quigley et al., 2017)). This results in five total faults defined, or one fault for the Kunayungku

441 rupture, two for the Lake Surprise west rupture, and two for the Lake Surprise east rupture, explored

442 in more detail in King et al. (2019) (in review).

443 Figure 14d presents portions of the scarp where more than two vertical displacement measurements of greater than $0.2 \mathrm{~m}$ occur within a distance of $1 \mathrm{~km}$ (data from (Bowman, 1991)). Applying cosmogenic erosion rates from lithologically and climatically analogous settings of Australia (5 - 10 $\mathrm{m} \mathrm{Myr}^{-1}$ Quigley et al. (2007)) suggests that $0.2 \mathrm{~m}$ of scarp height could be removed within $20-40$ kyrs, leaving $27.4 \mathrm{~km}$ of rupture length (i.e., $27.4 \mathrm{~km}$ of residual surface rupture with relief $\geq 0.2 \mathrm{~m}$ )

448 visible in the landscape. Based on these erosion rate estimates, the maximum recorded vertical offset 449 (1.8 m, Lake Surprise east) would be removed within 180 - 360 kyrs. Recurrence along the Lake 450 Surprise east rupture is limited by trenching results (Section 5.2) to $>46$ kyrs based on the earliest date for deposition of undeformed Eolian sediments (Crone et al., 1992). In this erosion rate calculation we assume that the scarp is shallowly underlain by quartzite bedrock and that the scarp erodes more rapidly than the surrounding terrain at rates commensurate with Quigley et al. (2007).

\subsection{Strike}

The average strike of the Kunayungku scarp is $109^{\circ}$, and a $1 \mathrm{~km}$ long segment at its eastern end strikes $063^{\circ}$. The western Lake Surprise scarp strikes on average $254^{\circ}$, not accounting for the very slight concavity through the middle of the rupture. The smaller length of rupture on the footwall of the western scarp strikes $264^{\circ}$. A line drawn between the point of dip inflection and the first step-over in the eastern Lake Surprise scarp has a strike of $098^{\circ}$ (I.e. the area of greatest curvature has a general E$\mathrm{W}$ trend). A line drawn between the first step over and last segment of the eastern lake surprise scarp has a strike of $118^{\circ}$. This measure discounts significant internal strike variation for each segment, including an average strike of $094^{\circ}$ for the first segment.

\subsection{Dip}

464 Most authors prefer fault dips based on aftershock defined planes and seismological data, rather than surface observations. Preferred dips from multiple primary sources using a variety of data are summarised in Table 4.

Only four surface measurements of dip are published, from four trenches described by Crone et al. (1992) (reproduced in Figure 12). The Kunayungku trench exposed multiple planes that accommodated slip dipping both NE and SW, but the authors believe the dominant fault is represented by a plane dipping $58^{\circ}$ towards the SW. The two trenches across the Lake Surprise west scarp were only $375 \mathrm{~m}$ apart but provide disparate dip measurements of $74^{\circ}$ (dip ranges between 65 $84^{\circ}$ along a well-defined plane) and $23^{\circ}$ towards the NW. The latter measurement is from fractures that the authors believe accommodated most of the slip at the surface, they do not believe these fractures represent the fault at depth. The Lake Surprise east trench exposed a network of planes that accommodated slip, dipping $28-30^{\circ} \mathrm{SW}$. Machette et al. (1991) and Crone et al. (1997) summarise the detailed trenching results and describe all ruptures as "reverse faults that dip $25 \pm 5^{\circ}$ "; a range intended to simplify the range of their original measurements.

Bowman (1991) produce four models for fault geometry and movement using surface offset data (described in Section 4.7 ). Their preferred model shows dips of $45^{\circ} \mathrm{SW}, 59^{\circ} \mathrm{NW}$ and $40^{\circ} \mathrm{SW}$ for the 
Table 4: Published dip measurements for the three surface ruptures / mainshocks

\begin{tabular}{|c|c|c|c|c|}
\hline Reference & Method & $\begin{array}{l}\text { Kunayungku / } \\
\text { TC1 }\end{array}$ & $\begin{array}{l}\text { Lake Surprise } \\
\text { west } / \text { TC2 }\end{array}$ & $\begin{array}{l}\text { Lake Surprise } \\
\text { east / TC3 }\end{array}$ \\
\hline $\begin{array}{l}\text { Crone et al. } \\
\text { (1992) }\end{array}$ & $\begin{array}{l}\text { Trench } \\
\text { measurements }\end{array}$ & $58^{\circ} \mathrm{SW}$ & $65-84^{\circ} \mathrm{NW}$ & $29^{\circ} \mathrm{SW}$ \\
\hline Bowman (1991) & $\begin{array}{l}\text { Modelling of } \\
\text { surface offsets }\end{array}$ & $45^{\circ} \mathrm{SW}$ & $59^{\circ} \mathrm{NW}$ & $40^{\circ} \mathrm{SW}$ \\
\hline $\begin{array}{l}\text { Choy and } \\
\text { Bowman (1990) }\end{array}$ & Focal mechanism & $35^{\circ} \mathrm{SW}$ & $70^{\circ} \mathrm{NW}$ & $45^{\circ} \mathrm{SW}$ \\
\hline $\begin{array}{l}\text { McCaffrey } \\
\text { (1989) }\end{array}$ & Focal mechanism & $45^{\circ} \mathrm{N}$ or $\mathrm{S}$ & $30^{\circ} \mathrm{N}$ or $\mathrm{S}$ & $38^{\circ} \mathrm{S}$ \\
\hline Bowman (1988) & Aftershock & $50^{\circ} \mathrm{SW}$ & $55^{\circ} \mathrm{NW}$ & $40^{\circ} \mathrm{SW}$ \\
\hline $\begin{array}{l}\text { Bowman et al. } \\
\text { (1990) }\end{array}$ & Aftershocks & $45^{\circ} \mathrm{SSW}$ & $55^{\circ} \mathrm{NNW}$ & $35^{\circ} \mathrm{SSW}$ \\
\hline $\begin{array}{l}\text { Jones et al., } \\
\text { (1991) }\end{array}$ & Aftershocks & & $55-60^{\circ} \mathrm{NNW}$ & $35^{\circ} \mathrm{SSW}$ \\
\hline
\end{tabular}

Choy and Bowman (1990) derive preferred fault dips of $35^{\circ} \mathrm{S}, 70^{\circ} \mathrm{N}$ and $45^{\circ} \mathrm{S}$ for $\mathrm{TC} 1, \mathrm{TC} 2$ and mechanisms and support their preferred choice with relocated aftershock depths and distributions (Bowman, 1988; Bowman et al., 1990; Choy and Bowman, 1990). Surprise west and $40^{\circ} \mathrm{S}$ on Lake Surprise east (Bowman et al., 1988), later refined to $45^{\circ} \mathrm{SSW}, 55^{\circ}$ NNW and $35^{\circ} \mathrm{SSW}$ (respectively) in Bowman et al. (1990) based on near-field temporary seismometer data.

Bowman et al. (1990) note that six aftershocks south of the Lake Surprise west scarp (inferred to dip north) may show a blind south-dipping fault. They suggest this is supported by seismic modelling of TS2 (Choy and Bowman, 1990; McCaffrey, 1989) which found greatest moment release associated with a SE dipping mechanism during a second sub-event.

\subsection{Morphology}

The $1: 500$ map of the Kunayungku rupture (Plate 1 of Crone et al. (1992)) shows back-thrusts up to $50 \mathrm{~m}$ long on the hanging-wall of the main rupture, hanging-wall folding extending $10-50 \mathrm{~m}$ from the rupture trace, and right-stepping rupture segments. Crone et al. (1992) describe only minor discrete rupture, with most of the Kunayungku scarp characterised by broad folding and monoclines along the rupture front.

Two 1 : 500 maps are presented for Lake Surprise west, with one showing continuous NW dipping rupture along a $150 \mathrm{~m}$ length and the other showing discontinuous SE dipping rupture segments 10 $20 \mathrm{~m}$ long (Plate 1 of Crone et al. (1992)). Both maps show $40-100 \mathrm{~m}$ fractures $5-10 \mathrm{~m}$ north of the rupture, parallel to them and associated with back thrusts on the hanging-wall (Plate 1 of Crone et al. (1992)). A single 1:500 map of the eastern Lake Surprise scarp is produced, showing a continuous south-dipping rupture with two sections of duplexing rupture $10-30 \mathrm{~m}$ long, and three sections of back thrust 10 - $40 \mathrm{~m}$ long (Plate 1 of Crone et al. (1992)).

Crone et al. (1992) provide descriptions of scarp morphology only as relates to the sections in the immediate vicinity of four trenches. The Lake Surprise east rupture morphology is described as a predominately continuous discrete rupture. This section represents the area of maximum vertical offset of all three scarp sections. The authors describe discrete rupture diminishing in height towards the ends of each segment, until the scarp is visible only as a gentle warping. Where the rupture 
515 duplexes, most of the offset is captured in the furthest segment (relative to the hanging-wall). For the

516 Lake Surprise west scarps, rupture consists of both small discrete ruptures or very broad ground warping across 10's of meters (maps and profiles on Plate 1 of Crone et al. (1992)). The shorter scarp mapped on the footwall of the western Lake Surprise scarp is described as a "gentle but pronounced steepening of the ground surface across a 20 - $50 \mathrm{~m}$ wide zone and, locally, as discontinuous mole track furrows" (Crone et al., 1992).

\subsection{Kinematics}

Folds and monoclines of the Kunayungku scarp are described as right-stepping en-echelon features (Crone et al., 1992), evident in the 1:500 map (plate 1, Crone et al. (1992)). Where the scarp displaces a road berm $25 \mathrm{~cm}$ of lateral offset is measured (Table 3, Crone et al. (1992), reproduced in Figure 12). The Lake Surprise west scarp is mapped as continuous with no step-overs, and the $1: 500$ maps show extensional cracks parallel to rupture with no indication of lateral movement or extension. Crone et al. (1992) record $10 \mathrm{~cm}$ of sinistral offset measured from an offset crack through a termite 528 mound.

The Lake Surprise east scarp shows multiple large scale right-stepping segments which may indicate a component of right lateral movement to thrusting. However, $20 \mathrm{~cm}$ and $40 \mathrm{~cm}$ of left-lateral movement are recorded in roads in the eastern and central portions of the scarp respectively (Crone et al., 1992). A pipeline that crosses the eastern Lake Surprise scarp was shortened by $1 \mathrm{~m}$ and showed no lateral component to shortening. Overall recorded lateral offsets are considered to have high uncertainties given the nature of offset features (road berms and termite mounds) and unknown method of measurement.

\subsection{Displacement}

The Tennant Creek rupture was documented with field work that included an aerial photographic survey, three $3 \mathrm{~km}$ and eighty $0.2 \mathrm{~km}$ levelling profiles across the rupture, and GPS located photos and field observations (Bowman, 1991). This work was conducted by the Australian Surveying and Lands Information Group who installed 170 temporary benchmarks, and conducted $170 \mathrm{~km}$ of double-run levelling (data published in (Bowman, 1991; Bowman and Jones, 1991) and reproduced in Figure 12).

Eighty short $200 \mathrm{~m}$ levelling profiles across all three scarps are interpreted to show the change in dip

544 between eastern and western Lake Surprise scarps, and variable vertical deformation along strike with 545 diminishing offset towards rupture ends (Bowman, 1992, 1991). Some profiles are excluded from the data based on pre-existing topography obscuring seismic offset. Three $3 \mathrm{~km}$ long profiles were produced, two across the Lake Surprise east scarp and one across the Kunayungku scarp. These show hanging-wall offset of $100-180 \pm 30 \mathrm{~cm}$ for the Lake Surprise east scarp, and $80 \pm 10 \mathrm{~cm}$ for Kunayungku scarp. Based on the graph of short profiles compared to these results for the longer profiles, it is estimated that distributed deformation on the Lake Surprise east scarp was $\sim 80 \mathrm{~cm}$ more than measured offset at the rupture tip, while offset at the Kunayungku rupture tip appears to match distributed offset (Bowman, 1991). Errors in levelling data may be in the order of $3-7 \mathrm{~cm}$ (Bowman, 1991).

554 Benchmarks installed between 1972 - 1973 were resurveyed in 1988 to determine offset differences 555 along $10-40 \mathrm{~km}$ sections (digitised in Figure 12) (Bowman, 1991; Bowman and Jones, 1991). Nine measurements are from reoccupied permanent benchmarks, but the majority of results come from relevelling approximate locations of temporary benchmarks removed after the 1972 - 1973 surveying. The permanent benchmark offset results have uncertainties up to $\pm 9.3 \mathrm{~cm}$, while the temporary benchmarks have estimated uncertainties up to $\pm 25 \mathrm{~cm}$ (Bowman, 1991). The author suggests that despite large errors, offsets are consistent with the locations of surface ruptures and therefore the data are useful for analysis. 
Eleven high resolution elevation profiles across the three Tennant Creek scarps are show in Figure 15 and capture scarp offset and distributed deformation in higher resolution than the original surveys (Bowman, 1991; Bowman and Jones, 1991). These profiles show Geolocated Photon Data (terrain height) from the Advanced Topographic Laser Altimeter System (ATLAS) instrument on board the Ice, Cloud and land Elevation Satellite-2 (ICESat-2) observatory (launched September 2018) (Neumann et al., 2019). Height data (original assigned confidence level $=4$ ) were cleaned by removing points with differences of $>1 \mathrm{~m}$ height relative to the average height of the next 5 points.

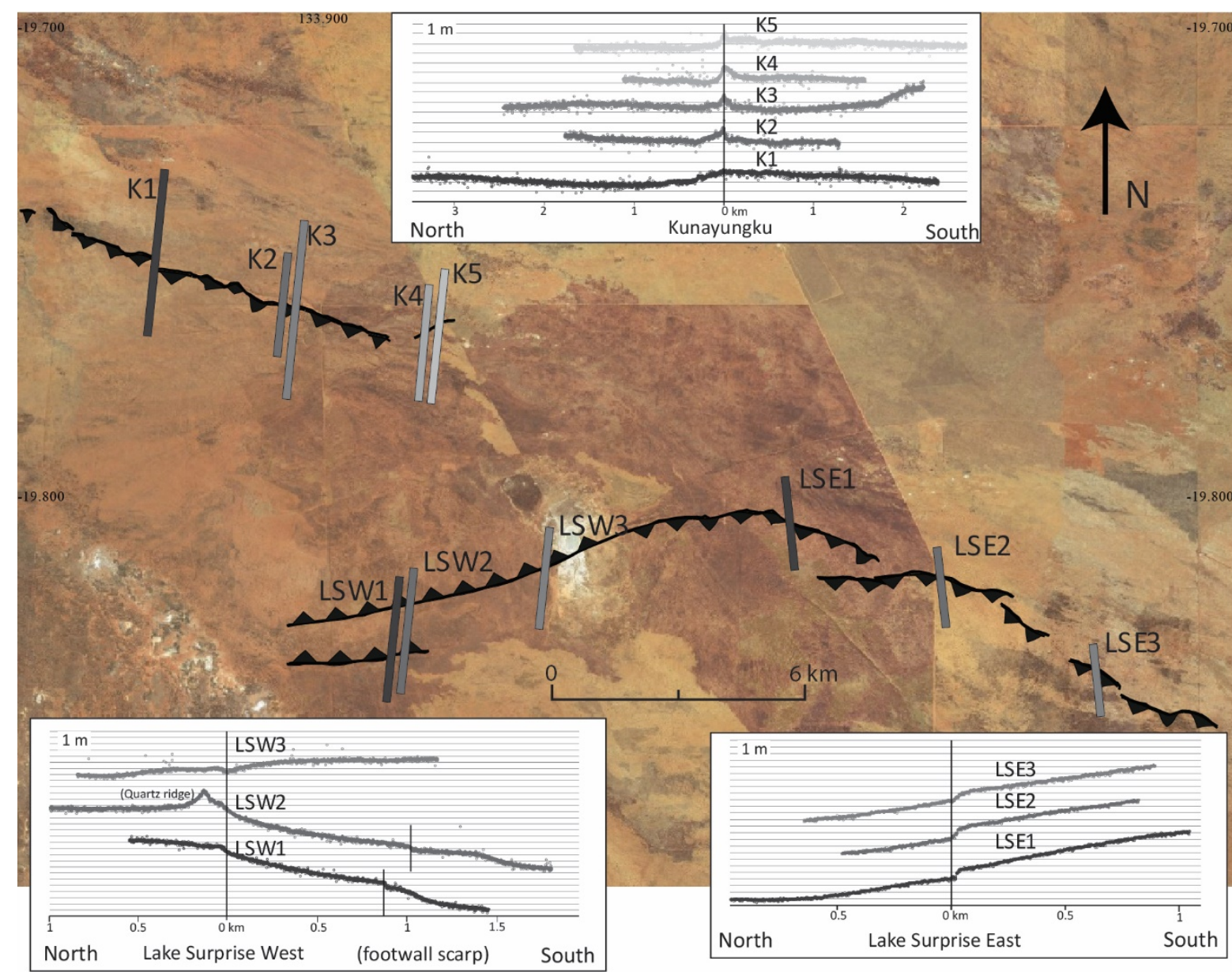

Figure 15: Terrain height profiles across the Tennant Creek scarps from NASA's Advanced Topographic Laser Altimeter System (ATLAS) instrument on board the Ice, Cloud and land Elevation Satellite-2 (ICESat-2) observatory (Neumann et al., 2019)

Profiles support offset along south-dipping planes for the Kunayungku and Lake Surprise east faults, and along a north-dipping plane for the Lake Surprise west faults. The magnitude of offset along the Kunayungku and Lake Surprise west footwall scarps appears to be higher than published vertical offset values ( $1-1.5 \mathrm{~m}$ offset compared to $0.9 \mathrm{~m}$ published maximum vertical displacement; $\sim 1 \mathrm{~m}$ offset compared to $0.74 \mathrm{~m}$ published maximum vertical displacement respectively). These profiles may therefore be capturing distributed deformation in the 10's of meters either side of rupture, that was not captured in the original survey (e.g. work by Gold et al. (2019) documenting the 2016

576 Petermann rupture). Profile offsets for the Lake Surprise west and east scarps appear to be within the range of published maximum vertical displacement values (1.1 $\mathrm{m}$ and $1.8 \mathrm{~m}$ respectively). This preliminary satellite derived height data indicates very little erosion across the scarps in the 30-31 years between 1988 and 2018/2019. 
Crone et al. (1992) show an along strike displacement profile presumably from surveying data presented in Bowman (1991) (the data source is not stated). These data are digitised and presented in Figure 16. This data are discussed in more detail in King et al. (2019).

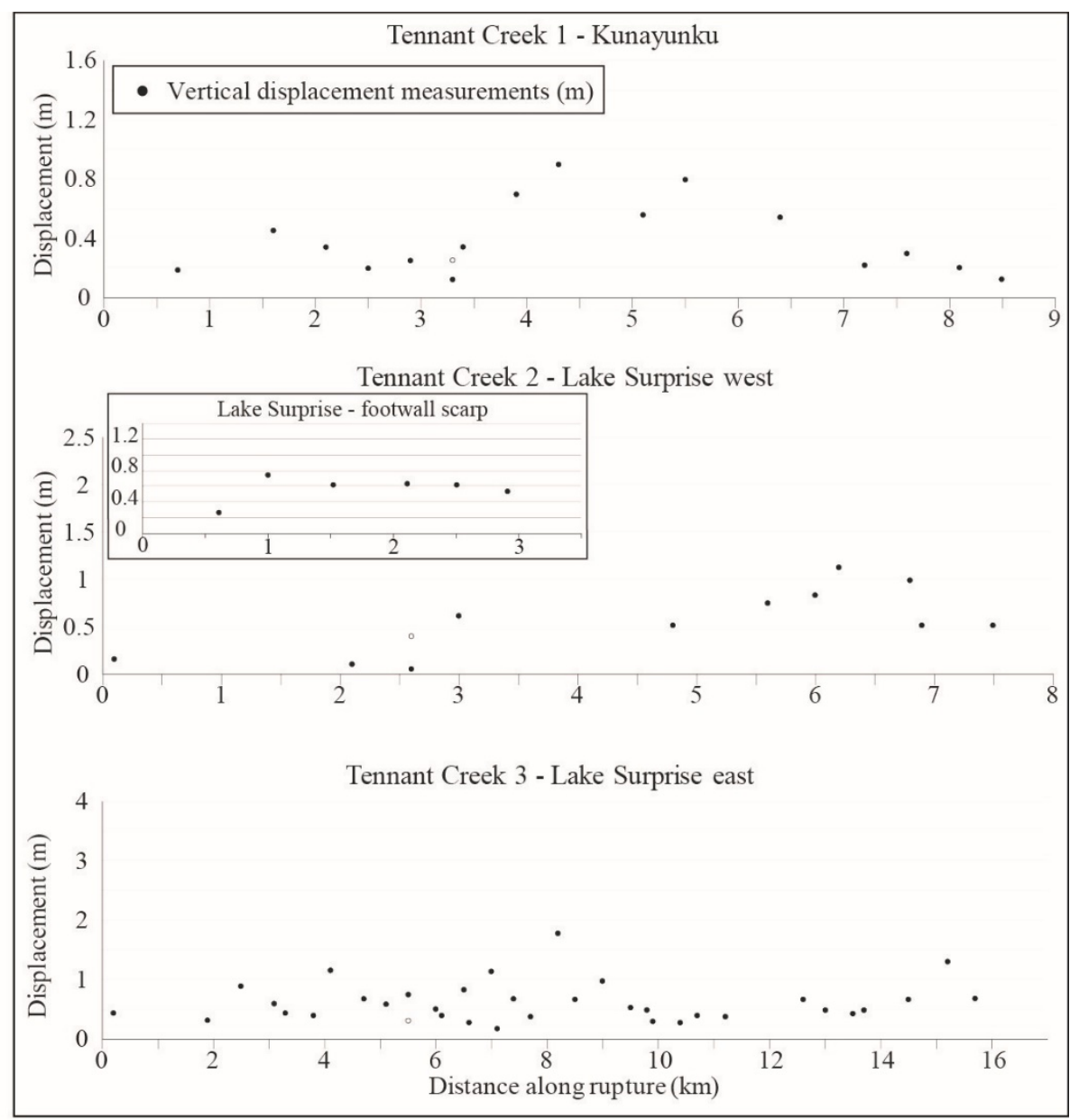

Figure 16: Vertical displacement measurements along the Tennant creek scarps, digitised from (Crone et al., 1992)

\subsection{Environmental damage}

The length and offsets of Tennant Creek scarps individually and together match descriptions for ESI $\mathrm{X}$ (Michetti et al., 2007). The length, offsets and descriptions of surface fractures / cracking as mapped in Crone et al. (1992) is classified as ESI VI - VII, with fissures up to ESI VIII. Vegetation damage is noted in the form of dead grasses and bushes resulting from root tear (Crone et al., 1992), these do not fit into the ESI-07 categories. No bedrock outcrops in the area were observed to have experienced rock falls, and nearby well data were analysed but no hydrological anomalies were documented (Bowman et al., 1990).

\section{Paleoseismic investigations of the 1988 Tennant Creek surface ruptures}

\subsection{Authors / mapping quality}

Crone et al. (1992) present comprehensive descriptions of four trenches dug across the ruptures and provide details of 54 samples taken for grain size analysis, electron-spin resonance, thermoluminescence, U-trend and U-series analysis, uranium isotope analysis, radiocarbon analysis, and chemical analysis (Table 8, Crone et al. (1992)). This data is summarised in Crone et al. (1997). Jones et al. (1991) note two trenches dug across the eastern Lake Surprise rupture that seem to be distinct to the Crone et al. (1992) trenches, but no descriptions of these two trenches are published. 


\section{$5.2 \quad$ Trenching}

600

601

602

603

604

605

606

607

608

609

610

611

612

613

614

615

616

617

618

619

620

621

622

623

624

625

626

627

628

629

630

631

632

633

634

635

636

637

638

639

640

641

642

643

644

645

\subsubsection{Identified units}

The trench logs of Crone et al. (1992) are comprehensive in their descriptions of units, including significant sampling to quantify grain size, age and deposition rate. Plate 2 of Crone et al. (1992) provides a summary of exposed units alongside interpreted trench logs.

The Crone et al. (1992) trench log across the Kunayungku scarp shows 'altered rock' at $\sim 2 \mathrm{~m}$ as bedrock, described as claystone with minor sand and carbonate nodules. These rocks likely relate to Proterozoic Wiso Basin sediments, or silicified paleochannel deposits (Bell et al., 2012; Magee, 2009), rather than Warramunga Province basement. There is no significant difference in the thickness of eolian sand, or depth to bedrock, across the Kunayungku scarp.

Two trenches across the Lake Surprise west scarp show significantly more lithological complexity than the Kunayungku trench. Bedrock in this location is described as 'quartzite' and 'iron-rich bedrock' and is exposed only on the hanging-wall sides of each trench. The bedrock is extensively oxidised and weathered, with the trench log showing a complex interaction of bedrock blocks that are interpreted to include shear bands and jointing fractures. Borehole logs on the hanging-wall of the rupture $\sim 2 \mathrm{~km}$ west of the trench locations show Wiso Basin or paleochannel sediments to $30 \mathrm{~m}$ (RN017672), $4 \mathrm{~km}$ north of the trench show diorite at $24 \mathrm{~m}$ (RN011688) and $\sim 5 \mathrm{~km}$ south-west on the footwall of the rupture limestone and clay to $36 \mathrm{~m}$ depth (RN013204) (limestone may be calcrete associated with paleo-channel deposits) (see Section 2). The authors interpret the fractured nature of bedrock exposed in the trench to indicate potential prior faulting in this location.

Surficial sediments are much thicker on the southern (footwall) sides of each trench and include eolian sand, angular gravels, ferricrete gravels and ferricrete. The gravels on the hanging-wall are interpreted to relate to a thin debris flow from the nearby quartz ridge from a high rainfall event prior to very thin $(\sim 10 \mathrm{~cm})$ deposition of eolian sand. In the second trench, angular gravels are seen to fill a small pocket in the underlying ferricrete. The authors interpret this as a fissure predating eolian deposition potentially relating to prior rupture (Crone et al., 1992), though it may also relate to any number of other surface erosional processes.

Relative to the northern, hanging-wall side of the trench, footwall eolian sand is $\sim 2 \mathrm{~m}$ thick in the first trench and $\sim 0.7 \mathrm{~m}$ thick in the second trench. In the second trench sand overlies angular debris, interpreted to be derived from basement blocks exposed on the hanging-wall of the trench. For both trenches, the height of bedrock on the northern side of the trench and thickness of eolian sediment on the south side is interpreted as a bedrock scarp of uncertain origin prior to the start of eolian deposition (Crone et al., 1997, 1992). The authors propose that the bedrock scarp could relate to a surface rupturing event, or represent an erosional feature from a palaeodrainage system. Quaternary deposits show no evidence of faulting or deformation prior to historic rupture.

The Lake Surprise east trench does not expose bedrock, with 2 - $3 \mathrm{~m}$ of eolian sand underlain with ferricrete extending to the bottom of the $4 \mathrm{~m}$ deep trench. The authors suggest that bedrock may exist at 4 - 5 m depth based on observations at the other trenches. A water-well drilled $\sim 200 \mathrm{~m}$ north of the trench site (on the footwall) shows sediments down to $230 \mathrm{~m}$ (RN010166). Another bore $\sim 6 \mathrm{~km} \mathrm{SE}$ of the trench (on the hanging-wall) shows weathered granites at $38 \mathrm{~m}$ (hard granite at $69 \mathrm{~m}$ ) overlain with clays and sandstone (RN012140). The deepest sample of eolian sand from this trench $(2.5 \mathrm{~m})$ shows a thermoluminescence age of $52 \pm 4 \mathrm{ka}$, interpreted to show eolian sediments began depositing in this area in the late Pleistocene. Thermoluminescence data from this and other trenches are used to derive a deposition rate of $3.2-4.8 \mathrm{~cm} / \mathrm{ka}$.

\subsubsection{Structural interpretations}

Trenching across the Kunayungku scarp shows that most of the uplift identified in levelling profiles ( $80 \pm 10 \mathrm{~cm}$ (Bowman, 1991)) is accommodated through hanging-wall folding rather than discrete slip 
646 along a confined, singular rupture plane. Offset is accommodated via multiple low to high angle 647 reverse fault strands in both the direction of overall fault dip and as back thrusts, generally with $<10$ $\mathrm{cm}$ individual offset (Crone et al., 1992). The main fault is a south-dipping structure that offsets bedrock by up to $30 \mathrm{~cm}$ and is central to a network of small faults and joints. The authors note that dip on this fault changes from $16^{\circ}$ to $58^{\circ}$ at the interface between eolian sands and claystone, indicating rheological control on faulting in the near-surface. Similarly, extensional cracking associated with hanging-wall folding is best expressed in the eolian sediments, and is generally not evident in the underlying claystone. The authors find no structural evidence to suggest prior faulting in this location.

The two Lake Surprise west trenches show more structural complexity than the Kunayungku trench.

655 Levelling profiles indicate up to $1 \mathrm{~m}$ of offset along a north-dipping fault (Bowman, 1991). However, in the first trench the only significant north-dipping structure mapped is a joint through eolian sand with no apparent offset. A south-dipping reverse fault is mapped on the trench log between disjointed bedrock units interpreted as an ancient south-dipping shear zone which accommodated some of the shortening related to the north-dipping historical event (Crone et al., 1992). The second trench shows steep north-dipping structures through bedrock, which the authors interpret as Precambrian shear as they do not extend into the overlying ferricrete (Crone et al., 1992). They suggest that most of the 1988 offset is accommodated in a $\sim 10 \mathrm{~cm}$ wide brecciated zone dipping $65-84^{\circ}$ north, with no measurable offsets due to the weathered nature of bedrock.

Similar to the Kunayungku scarp, the Lake Surprise east trench shows multiple south-dipping rupture strands accommodating offset, connected by networks of small north-dipping joints. Only two of these strands are shown to rupture to the surface at the location of the discrete rupture. The other strands terminate at a mapped soil layer and the authors note that the minimal system of roots in this topmost layer may have constrained deformation to the subsurface, except along the main fault strand. Near vertical extensional cracks are mapped on the hanging-wall due to minor folding. The authors interpret all the identified structures to relate to the 1988 event, with no evidence of prior rupture.

Crone et al. (1992) suggest that the location of Lake Surprise at the dip inflection point and change in strike between eastern and western Lake Surprise ruptures is evidence of structural complexities in the subsurface. They note that calcrete mounds around the lake show evidence of active ground water flow which may relate to subsurface structures, and suggest that Lake Surprise showed the lowest offset measurements from levelling profiles supportive of structural complexity creating a rupture barrier. The authors imply that this barrier may have prevented any prior rupture along the Lake Surprise west scarp (as postulated based on the pre-existing bedrock scarp) propagating across to the Lake Surprise east or Kunayungku scarps (which show no evidence of prior rupture) (Crone et al., 1992).

\subsection{Summary of evidence for prior rupture along the Lake Surprise west scarp}

The Lake Surprise west scarp runs along a $\sim 4.8 \mathrm{~km}$ long quartz ridge (Bowman, 1992; Bowman et al., 1990; Crone et al., 1992). Most authors describe this quartz ridge as an "ancient mineralized fault or fault zone" (Crone et al., 1992) and infer this coincidence of location to suggest the Lake Surprise west fault either reactivated, or at least was controlled by, this geological feature. Slip is accommodated along north and south-dipping fractures in the first trench, and steeply north-dipping narrow shear band in the second trench. Both trenches show a distinct basement scarp of complex jointed and altered basement under thin eolian cover on the north side, with thick eolian cover on the south side including evidence of alluvium derived from the bedrock (Crone et al., 1992). This may relate to palaeodrainage erosion along a pre-existing basement structure (as indicated by the quartz ridge, and geophysical interpretation of bedrock (Figure 2)), or to prior neotectonic reactivation prior to the deposition of Quaternary sediments. 
693 Three lines of evidence are presented to support prior rupture along the Lake Surprise west scarps: an

694 infilled hole above bedrock and below eolian sands suggested to be an infilled coseismic fissure;

695 fractures that extend through bedrock into some, but not all, quaternary sediment layers; and the

696 inferred height of pre-existing bedrock scarp (>1.65 m) suggesting the pre-existing scarp was "at

697 least equal in size to the historical scarp". This third piece of evidence shows a bedrock scarp at least

698 twice as high as the historic scarp $(0.8 \mathrm{~m})$ after undergoing an unknown length of erosion prior to

699 sediment deposition (i.e. the scarp may have been much higher). The second piece of evidence may

700 support prior rupture, but fractures which do not extend to the surface are observed in the Lake

701 Surprise east scarp and at least one other historic surface rupturing event (Meckering (Clark and

702 Edwards, 2018)).

\section{6. Discussion}

\subsection{Basement structural controls on the 1987 - 2019 Tennant Creek sequence}

Available geological and geophysical data suggests that pre-existing basement structures imparted strong controls on the fault location and orientation of all three 1988 surface ruptures, and the 2019 aftershock. All historically rupturing faults, as documented as surface ruptures, or imaged in InSAR, are sub-parallel to linear gravity anomalies, coincident with the edges of a magnetic high and coincident with basement structures identified in the interpreted geology map of Johnstone and Donnellan (2001) (Figure 17). All three surface ruptures and the 2019 fault coincide with the location of the Palparti paleo-valley (Bell et al., 2012), which is expressed in the mapped surface geology

712 (Figure 17d). Shallow geophysical techniques and drill logs across paleo-valley sediments may

713 provide an opportunity to investigate prior paleoseismic activity of these faults. 

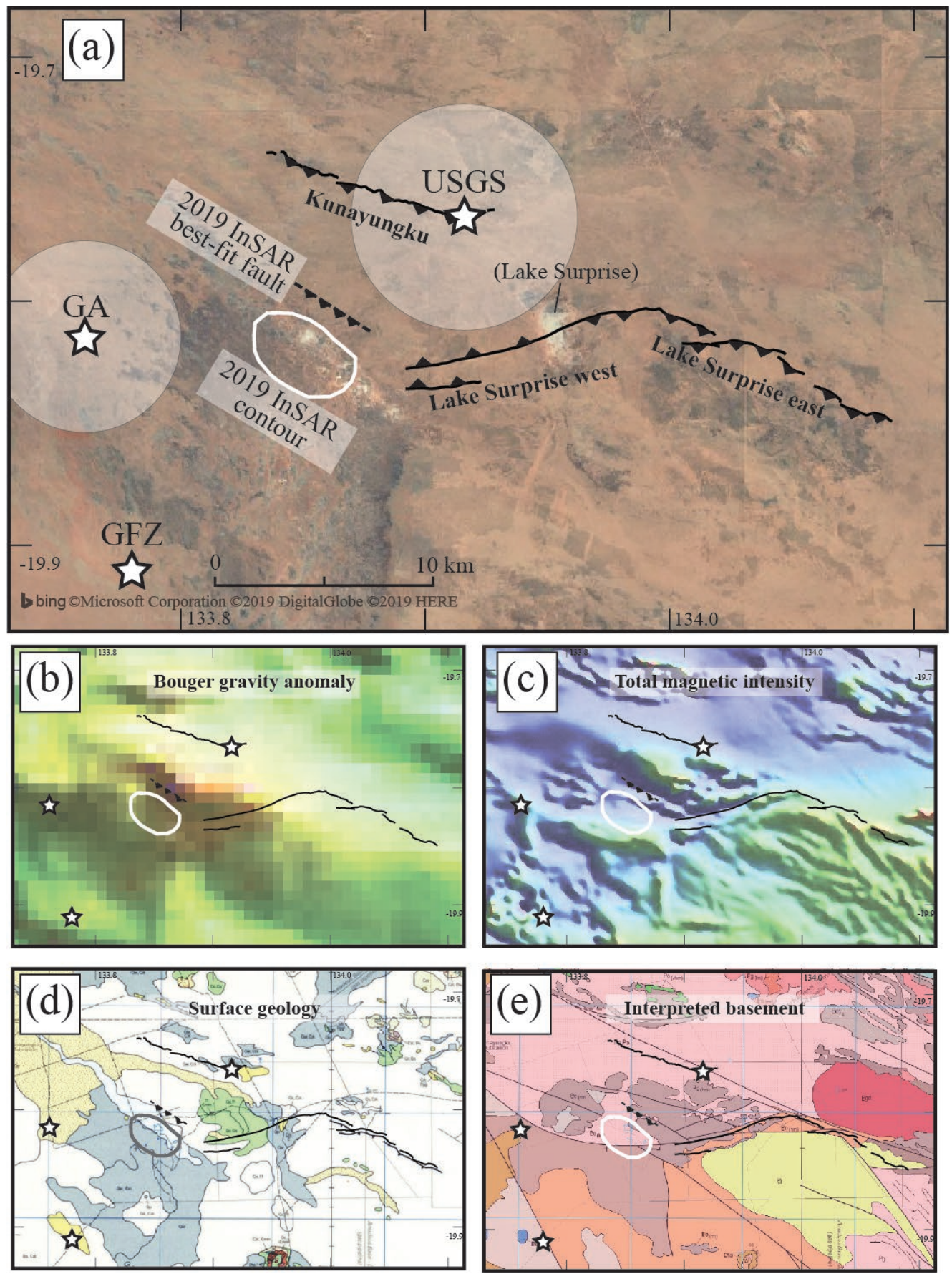

Figure 17: (a) map of 1988 surface ruptures, $2019 M_{w} 5.0$ epicentres, and InSAR contours and best-fit fault model for 2019 event (b)-(e) same map components as (a) showing (b) national bouguer gravity anomaly map (c) national total magnetic intensity (d) surface geology map (see Figure 4, for legend and details) (e) interpreted basement geology (see Figure 2 for legend and details)

\section{Conclusions}

715 The Tennant Creek seismic sequence began with four earthquakes of $\mathrm{M}_{\mathrm{L}} 4.9$ - 5.4 in January 1987, 716 includes the three $\mathrm{M}_{\mathrm{w}} 6.3,6.4$ and 6.6 surface rupturing events of $22^{\text {nd }}$ January 1988, and includes a 717 prolonged aftershock sequence punctuated by a $\mathrm{M}_{\mathrm{w}} 5.0$ event on a shallow blind fault on $1^{\text {st }}$ August 718 2019. Available data suggests that the seismicity is occurring along or coincident with pre-existing 719 basement structures, and there is no strong evidence to support prior Cenozoic rupture along these 720 features. 
This research was funded by the Australian Research Council through Discovery Grant \#DP170103350. T. King received funding through the Australian Government Research Training Program Scholarship. We would like to acknowledge the Warumungu people as the traditional custodians of the land on which this surface rupture occurred, and where the data described in this paper were collected. The authors declare no conflict of interest.

\section{References}

Allen, T., Griffin, J., Clark, D., 2018a. The 2018 National Seismic Hazard Assessment: Model input files (GA Record 2018/032), 2018/32. ed. Geoscience Australia, Canberra, ACT. https://doi.org/http://dx.doi.org/10.11636/Record.2018.032

Allen, T., Leonard, M., Ghasemi, H., Gibson, G., 2018b. The 2018 National Seismic Hazard Assesment: Earthquake epicentre catalogue (GA Record 2018/30). Geoscience Australia, Commonwealth of Australia, Canberra, ACT. https://doi.org/http://dx.doi.org/10.11636/Record.2018.030

Bell, J.G., Kilgour, P.L., English, P.M., Woodgate, M.F., Lewis, S.J., Wischusen, J.D.H., 2012. WASANT Palaeovalley Map - Distribution of Palaeovalleys in Arid and Semi-arid WA-SA-NT. https://doi.org/http://pid.geoscience.gov.au/dataset/ga/73980

Betts, P.G., Giles, D., Lister, G.S., Frick, L.R., 2002. Evolution of the Australian lithosphere. Aust. J. Earth Sci. 49, 661-695. https://doi.org/10.1046/j.1440-0952.2002.00948.x

Biasi, G.P., Wesnousky, S.G., 2017. Bends and ends of surface ruptures. Bull. Seismol. Soc. Am. 107, 2543-2560. https://doi.org/10.1785/0120160292

Biasi, G.P., Wesnousky, S.G., 2016. Steps and gaps in ground ruptures: Empirical bounds on rupture propagation. Bull. Seismol. Soc. Am. 106, 1110-1124. https://doi.org/10.1785/0120150175

Blake, D.H., Page, R.W., 1988. The Proterozoic Davenport province, central Australia: regional geology and geochronology. Precambrian Res. 40-41, 329-340. https://doi.org/10.1016/03019268(88)90074-5

Boncio, P., Liberi, F., Caldarella, M., Nurminen, F.C., 2018. Width of surface rupture zone for thrust earthquakes: Implications for earthquake fault zoning. Nat. Hazards Earth Syst. Sci. 18, 241256. https://doi.org/10.5194/nhess-18-241-2018

Bouniot, E., Jones, T., McCue, K., 1990. The pattern of 1987 sequence at Tennant Creek, NT, in: Gregson, P.J. (Ed.), Recent Intraplate Seismicity Studies Symposium, Perth Western Australia (BMR Record 1990/44). Bureau of Mineral Resources, Geology and Geophysics, Canberra, ACT. https://doi.org/http://pid.geoscience.gov.au/dataset/ga/14335

Bowman, J.R., 1992. The 1988 Tennant Creek, Northern Territory, earthquakes: A synthesis. Aust. J. Earth Sci. 39, 651-669. https://doi.org/10.1080/08120099208728056

Bowman, J.R., 1991. Geodetic evidence for conjugate faulting during the 1988 Tennant Creek, Australia earthquake sequence. Geophys. J. Int. 107, 47-56. https://doi.org/10.1111/j.1365246X.1991.tb01155.x

Bowman, J.R., 1988. Constraints on locations of large intraplate earthquakes in the Northern Territory, Australia from observations at the Warramunga seismic array. Geophys. Res. Lett. 15, 1475-1478. https://doi.org/10.1029/GL015i013p01475

Bowman, J.R., Dewey, J.W., 1991. Relocation of teleseismically recorded earthquakes near Tennant Creek, Australia: Implications for midplate seismogenesis. J. Geophys. Res. 96, 11,973-11,979. https://doi.org/10.1029/91JB00923 
Bowman, J.R., Gibson, G., Jones, T., 1990. Aftershocks of the 1988 January 22 Tennant Creek, Australia Intraplate Earthquakes: Evidence For A Complex Thrust-Fault Geometry. Geophys. J. Int. 100, 87-97. https://doi.org/10.1111/j.1365-246X.1990.tb04570.x

Bowman, J.R., Gibson, G., Jones, T., 1988. Faulting process of the January 22, 1988 Tennant Creek, Northern Territory, Australia earthquakes, in: Abstracts for the AGU Fall Meeting 1988: EoS Transactions. p. 1301. https://doi.org/https://doi.org/10.1029/89EO00248

Bowman, J.R., Jones, T., 1991. Post-seismic surveys of the epicentral area of the 1988 Tennant Creek, N.T., earthquakes (BMR Record 1992/002). Bureau of Mineral Resources, Geology and Geophysics, Canberra, Australia. https://doi.org/http://pid.geoscience.gov.au/dataset/ga/14510

Bowman, J.R., Yong, C., 1997. Case 22 A Seismicity Precursor to a Sequence of M 6.3-6.7 Midplate Earthquakes in Australia. Pure Appl. Geophys. 149, 61-78. https://doi.org/10.1007/BF00945161

Bullock, P.W.B., 1977. Tennant Creek gravity and magnetic survey, Northern Territory, 1973 (BMR Record 1977/30). Bureau of Mineral Resources, Geology and Geophysics, Canberra, Australia. https://doi.org/http://pid.geoscience.gov.au/dataset/ga/13559

Cawood, P.A., Korsch, R.J., 2008. Assembling Australia: Proterozoic building of a continent. Precambrian Res. 166, 1-35. https://doi.org/10.1016/j.precamres.2008.08.006

Choy, G.L., Bowman, J.R., 1990. Rupture process of a multiple main shock sequence: analysis of teleseismic, local and field observations of the Tennant Creek, Australia, earthquakes of January 22, 1988. J. Geophys. Res. 95, 6867-6882. https://doi.org/10.1029/JB095iB05p06867

Claoué-Long, J., Maidment, D., Donnellan, N., 2008. Stratigraphic timing constraints in the Davenport Province, central Australia: A basis for Palaeoproterozoic correlations. Precambrian Res. 166, 204-218. https://doi.org/10.1016/j.precamres.2007.06.021

Clark, D., Edwards, M., 2018. 50th anniversary of the 14th October 1968 Mw 6.5 (Ms 6.8) Meckering earthquake (GA Record 2018/39). Geoscience Australia, Commonwealth of Australia, Canberra, ACT. https://doi.org/http://dx.doi.org/10.11636/Record.2018.039

Clark, D., Mcpherson, A., Allen, T., De Kool, M., 2014. Coseismic surface deformation caused by the 23 March 2012 Mw 5.4 Ernabella (Pukatja) earthquake, central Australia: Implications for fault scaling relations in cratonic settings. Bull. Seismol. Soc. Am. 104, 24-39. https://doi.org/10.1785/0120120361

Clark, D., McPherson, A., Van Dissen, R.J., 2012. Long-term behaviour of Australian stable continental region (SCR) faults. Tectonophysics 566-567, 1-30. https://doi.org/10.1016/j.tecto.2012.07.004

Compston, D.M., 1995. Time constraints on the evolution of the Tennant Creek Block, northern Australia. Precambrian Res. 71, 107-129. https://doi.org/10.1016/0301-9268(94)00058-Y

Crone, A.J., De Martini, P.M., Machette, M.N., Okumura, K., Prescott, J.R., 2003. Paleoseismicity of Two Historically Quiescent Faults in Australia: Implications for Fault Behavior in Stable Continental Regions. Bull. Seismol. Soc. Am. 93, 1913-1934. https://doi.org/10.1785/0120000094

Crone, A.J., Machette, M.N., Bowman, J.R., 1997. Episodic nature of earthquake activity in stable continental regions revealed by palaeoseismicity studies of Australian and North American quaternary faults. Aust. J. Earth Sci. 44, 203-214. https://doi.org/10.1080/08120099708728304 
Crone, A.J., Machette, M.N., Bowman, J.R., 1992. Geologic Investigations of the 1988 Tennant Creek, Australia, Earthquakes - Implications for Paleoseismicity in the Stable Continental Regions (USGS Bulletin 2032-A). U.S. Geological Survey, Washington, USA. https://doi.org/https://doi.org/10.3133/b2032A

Denham, D., 1988. Australian seismicity - the puzzle of the not-so-stable continent. Seismol. Res. Lett. 59, 235-240. https://doi.org/https://doi.org/10.1785/gssrl.59.4.235

Donnellan, N., 2013. Chapter 9: Warramunga Province, in: Ahmad, M., Munson, T.J. (Eds.), Geology and Mineral Resources of the Northern Territory, Special Publication 5. Northern Territory Geological Survey.

Donnellan, N., Hussey, K.J., Morrisson, R.S., Kruse, P.D., 1998. Tennant Creek 1:250 000 Geology. Edition 2.

Donnelly, K.E., Morrison, R.S., Hussey, K.J., Ferenczi, P.A., Kruse, P.D., 1999. Tennant Creek 1:250000 Explanatory Notes, Geological Map Series. Northern Territory Geological Survey, Darwin, Australia. https://doi.org/10.1017/CBO9781107415324.004

Ekström, G., Nettles, M., Dziewoński, A.M., 2012. The global CMT project 2004-2010: Centroidmoment tensors for 13,017 earthquakes. Phys. Earth Planet. Inter. 200-201, 1-9. https://doi.org/10.1016/j.pepi.2012.04.002

Gold, R.D., Clark, D., Barnhart, W.D., King, T., Quigley, M., Briggs, R.W., 2019. Surface rupture and distributed deformation revealed by optical satellite imagery: The intraplate $2016 \mathrm{Mw} 6.0$ Petermann Ranges earthquake, Australia. Geophys. Res. Lett. https://doi.org/10.1029/2019GL084926

Johnston, A.C., Coppersmith, K.J., Cornell, C.A., 1994. The earthquakes of stable continental regions, in: Electric Power Research Institute Report TR-102261-VI. Palo Alto, California.

Johnstone, A., Donnellan, N., 2001. Tennant Creek 1:250 000 Integrated Interpretation of Geophysics and Mapped Geology. Edition 1. Northern Territory Geological Survey, Alice Springs, Alice Springs, Australia.

Jones, T., Gibson, G., McCue, K., Denham, D., Gregson, P.J., Bowman, J.R., 1991. Three large intraplate earthquakes near Tennant Creek, Northern Territory, on 22 January 1988. BMR J. Aust. Geol. Geophys. 12, 339-343. https://doi.org/http://pid.geoscience.gov.au/dataset/ga/81300

King, T.R., Quigley, M.C., Clark, D., 2019. Surface-rupturing historical earthquakes in Australia and their environmental effects: new insights from re-analyses of observational data. Geosciences.

Leonard, M., 2014. Self-consistent earthquake fault-scaling relations: Update and extension to stable continental strike-slip faults. Bull. Seismol. Soc. Am. 104, 2953-2965. https://doi.org/10.1785/0120140087

Leonard, M., 2010. Earthquake fault scaling: Self-consistent relating of rupture length, width, average displacement, and moment release. Bull. Seismol. Soc. Am. 100, 1971-1988. https://doi.org/10.1785/0120090189

Leonard, M., 2008. One hundred years of earthquake recording in Australia. Bull. Seismol. Soc. Am. 98, 1458-1470. https://doi.org/10.1785/0120050193

Leonard, M., Ripper, I.D., Yue, L., 2002. Australian earthquake fault plane solutions (GA Record 2002/019), 2002/19. ed. Canberra, ACT. https://doi.org/http://pid.geoscience.gov.au/dataset/ga/37302 
Machette, M.N., Crone, A.J., Bowman, J.R., Prescott, J.R., 1991. Surface ruptures and deformation associated with the 1988 Tennant Creek and 1986 Marryat Creek, Australia, intraplate earthquakes, in: Abstracts of the U.S. Geological Survey, Central Region; 1991 Poster Review. p. 27. https://doi.org/https://doi.org/10.3133/ofr91582

Magee, J.W., 2009. Palaeovalley Groundwater Resources in Arid and Semi-Arid Australia A Literature Review Palaeovalley Groundwater Resources in Arid and Semi-Arid Australia - A literature review.

Maidment, D.W., Huston, D.L., Donnellan, N., Lambeck, A., 2013. Constraints on the timing of the Tennant Event and associated Au-Cu-Bi mineralisation in the Tennant Region, Northern Territory. Precambrian Res. 237, 51-63. https://doi.org/10.1016/j.precamres.2013.07.020

McCaffrey, R., 1989. Teleseismic investigation of the January 22, 1988 Tennant Creek, Australia, earthquakes. Geophys. Res. Lett. 16, 413-416. https://doi.org/10.1029/GL016i005p00413

Michetti, A.M., Esposito, E., Guerrieri, L., Porfido, S., Serva, L., Tatevossian, R.E., Vittori, E., Audemard M., F.A., Azuma, T., Clague, J., Comerci, V., Gurpinar, A., McCalpin, J.P., Mohammadioun, B., Morner, N.A., Ota, Y., Roghozhin, E., 2007. Intensity Scale ESI 2007, Memorie Descrittive della Carta Geologica d'Italia, Special Volume 74. APAT, Rome 2007.

Mohammadi, H., Quigley, M., Steacy, S., Duffy, B., 2019. Effects of source model variations on Coulomb stress analyses of a multi-fault intraplate earthquake sequence. Tectonophysics 766, 151-166. https://doi.org/10.1016/j.tecto.2019.06.007

Moss, R.E.S., Ross, Z.E., 2011. Probabilistic fault displacement hazard analysis for reverse faults. Bull. Seismol. Soc. Am. 101, 1542-1553. https://doi.org/10.1785/0120100248

Neumann, T.A., Brenner, A., Hancock, D., Robbins, J., Luthcke, S.B., Harbeck, K., Lee, J., Gibbons, A., Saba, J., Brunt, K., 2019. ATLAS/ICESat-2 L2A Global Geolocated Photon Data, Version 1. NSIDC: National Snow and Ice Data Center, Boulder, Colorado USA. https://doi.org/https://doi.org/10.5067/ATLAS/ATL03.001

Quigley, M.C., Mohammadi, H., Jimenez, A., Duffy, B.G., 2017. Multi-fault earthquakes with kinematic and geometric rupture complexity : how common ? INQUA Focus Group Earthquake Geology and Seismic Hazards, in: 8th International INQUA Meeting on Paleoseismology, Active Tectonics and Archeoseismology (PATA), 13 - 16 November, 2017, New Zealand.

Quigley, M.C., Sandiford, M., Fifield, L.K., Alimanovic, A., 2007. Landscape responses to intraplate tectonism: Quantitative constraints from 10Be nuclide abundances. Earth Planet. Sci. Lett. 261, 120-133. https://doi.org/10.1016/j.epsl.2007.06.020

Stein, S., Liu, M., 2009. Long aftershock sequences within continents and implications for earthquake hazard assessment. Nature 462, 87-89. https://doi.org/10.1038/nature08502

Verhoeven, T.J., Russell, P.W., 1981. Tennant Creek Water Supply 1979 - 1980 Source Investigation [Kelly Well] (Report 27/1981). Department of Transport and Works, Alice Springs, Australia. https://doi.org/http://hdl.handle.net/10070/229202

Wells, D.L., Coppersmith, K.J., 1994. New Empirical Relationships among Magnitude, Rupture Length, Rupture Width, Rupture Area, and Surface Displacement. Bull. Seismol. Soc. Am. 84, 974-1002.

Wesnousky, S.G., 2008. Displacement and geometrical characteristics of earthquake surface ruptures: Issues and implications for seismic-hazard analysis and the process of earthquake rupture. Bull. Seismol. Soc. Am. 98, 1609-1632. https://doi.org/10.1785/0120070111 